\title{
Circular Innovation Framework: Verifying Conceptual to Practical Decisions in Sustainability-Oriented Product-Service System Cases
}

\author{
Daniel Guzzo ${ }^{1,2}{ }^{\oplus}$, Adriana Hofmann Trevisan ${ }^{1}$, Marcia Echeveste ${ }^{3}$ and \\ Janaina Mascarenhas Hornos Costa ${ }^{1, *}$ \\ 1 Production Engineering Department, São Carlos School of Engineering, University of São Paulo, \\ Avenida Trabalhador Sãocarlense 400, São Carlos, SP 13566-590, Brazil; daniel.guzzo.costa@usp.br (D.G.); \\ adrianatrevisan@usp.br (A.H.T.) \\ 2 Insper Institute of Education and Research, Rua Quatá 300, Vila Olímpia, São Paulo, SP 04546-042, Brazil \\ 3 Industrial Engineering Department, Federal University of Rio Grande do Sul, Avenida Osvaldo Aranha 99, \\ Porto Alegre, RS 90035-190, Brazil; echeveste@producao.ufrgs.br \\ * Correspondence: janainacosta@usp.br
}

Received: 23 May 2019; Accepted: 6 June 2019; Published: 12 June 2019

check for updates

\begin{abstract}
Product-service systems (PSSs) have significant sustainability potential. However, limited knowledge is available on the choices to develop circular PSS solutions. The goal of this paper is to provide a circular innovation framework containing circular strategies to facilitate the decision-making in PSS circular innovation. A systematic literature review in combination with content analysis underpinned this research. The strategies were investigated in 45 PSS cases from the literature. A coding system was designed and employed to identify and organize the circular strategies and practices. The statistics techniques employed were frequency and co-occurrence analysis, which aimed to describe the synergies among strategies. The framework proposed contains twenty-one circular strategies. The practical perspective comprises the seventy-seven practices used for the operationalization of strategies. The framework can assist organizations in making strategic to tactical decisions when developing circular PSS solutions. The paper provides a panorama of the strategy applications among the PSS types. Finally, the research approach can be employed to continuously develop an understanding of the application of circular strategies in PSS and other fields.
\end{abstract}

Keywords: circular economy; business model innovation; product-service systems

\section{Introduction}

The circular economy (CE) is considered as a possible path towards sustainable development [1]. It is characterized as an advanced economic and harmonious industrial system [2,3], where business model innovation (BMI) is a central engine to unlock the potential contribution of value networks towards the CE [4-6]. Business models (BMs) are conceptual frameworks, which represent the logic of how a specific business or solution functions [7], i.e., the rationale through which value is proposed to customers, and how organizations and individuals create and deliver value to enable those intended benefits [8]. The BM concept is a remarkable conceptual framework to understand and envision paths towards circular solutions.

Linear and circular BMs are often characterized to distinguish preferable solutions towards the CE. Linear BMs, commonly referred to as business as usual, are considered as businesses that create and deliver value, mainly dependent on the inflow of raw materials through manufacturing to satisfy consumption needs [5]. On the contrary, a circular BM makes use of the value of idle products, 
functional parts and components, discarded materials, and renewable sources of energy and material to overcome linear solutions [2].

The circular path, i.e., the transition to a circular BM, implies the identification of forms of value creation, which fill the gaps among linear models dependent on product ownership and the flow of virgin materials, to circular models which intensify the use of the value contained in products, materials, and energy [5]. Companies face challenges to transition from a linear business model to a circular one [9]. Nevertheless, it is imperative to accommodate the transformation and use of resources and integrate intangibles to solutions to potentialize the benefits and mitigate the environmental impacts. It is evidently necessary to consider the mix of products and services that constitute a potentially circular BM.

From this vantage point, product-service systems (PSSs) become a fundamental object of study. PSSs are solutions which consist of tangible products and infrastructure and intangible services designed to meet stakeholders' needs $[10,11]$. Conceptually, a PSS is a type of business solution with the potential for positive environmental impacts [12-14]. For instance, in product-oriented services, product functionality can be retained through maintenance services and improved through information obtained during usage [15]. The environmental advantages are potentially more significant when an intense and sequential use of products is carried out, as in use-oriented PSSs [15]. Additionally, in result-oriented services, there is an incentive to optimize the use of materials and energy because the PSS provider is responsible for all the costs related to the results provided to customers [16]. The sustainability potential is undeniable.

In the CE literature, the mix of products and services also receives special consideration. PSSs are commonly referred to as access or utilization-oriented models and bear high sustainability potential because they enhance the utilization level of products and enable other circular models [2,6,17]. Indeed, there are indications of synergies among circular strategies and the types of PSS, which can incorporate strategies differently [18]. More than a type of BM that leads to sustainability by itself can enable and potentialize other circular forms of value creation and delivery.

However, the intrinsic sustainability potential of PSSs has not been fully mastered [19]. For instance, impacts are potentially worse in PSS solutions when services are secondary compared to selling more products, or when shared responsibility leads to less conscientious behavior of users [20]. Additionally, immense care is prescribed to design and implement PSS solutions which are genuinely circular [21].

Considering the latent potential of PSSs to enable circular solutions and help to achieve sustainability, it is mandatory to understand the decisions that can lead to more sustainable PSS solutions. The strategies that can be adopted in the design and operation of a circular PSS have been minor or superficially addressed. Moreover, there is a limitation of studies that explore how PSS providers can boost their solutions to a more sustainable level.

Through an extensive literature review, Bocken et al. [22] have mapped 13 tools that can be used to design a circular BMI. In their survey, this study did not find any tool that addresses circular strategies. Indeed, the authors argue the need for works aiming to "increase understanding of the CBMI process, overcome specific organizational barriers and identify the most fitting business models" [22]. The BMI must comprise a set of strategic to tactical choices towards the envisioned competitive advantage [23]. Considering in particularly a PSS business model, specific mechanisms to create, deliver, and capture value must be considered [15]. Thus, this work aims to propose a circular innovation framework to facilitate decision-making in circular BMI by offering concepts, strategies, and practices to develop circular PSS solutions.

Three refined research questions arose:

1. Which are the known strategies that enable circularity?

2. Which of these strategies are applied in PSS solutions? Does their application differ among PSS types?

3. What are the practices that enable operationalizing such strategies in PSS solutions? 
A systematic literature review was used to identify PSS cases that discuss triple-bottom-line aspects and impacts. Content analysis was applied to identify to which extent and how circular strategies were applied in the set of sustainability-oriented PSS cases identified. A multi-perspective framework was built to explicitly show conceptual, strategic, and operational perspectives to enable circular solutions. Operational practices that enable strategies were elaborated from the know-how contained in the identified cases. Occurrence and co-occurrence analyses make explicit the synergies among different strategies.

This study provides a synthesis of circular strategies that can be adopted in PSS business models to deliver greater value to the client, provide economic gains and at the same time make the most effective use of resources. The circular innovation framework has substantial potential to assist organizations in making strategic to tactical decisions to develop circular PSS solutions.

The structure of this paper is described as follows. Section 2 presents the methodological approach used for data collection and analysis. The circular innovation framework is detailed in Section 3. In Section 4, the practices to operationalize circular strategies are described. Occurrence and co-occurrence analyses are detailed in Section 5. Finally, Section 6 encompasses the contributions, limitations, and future research avenues of this work.

\section{Research Methodology}

A systematic literature review [24] in combination with content analysis was applied to resolve the research questions. Content analysis was applied in combination because it is a replicable method to categorize words, strings, and figures to enact common meaning among segments of information [25]. The two stages of identifying and analyzing sustainable PSS cases and facilitating decision-making in circular BMI are described in the following subsections.

\subsection{Systematic Literature Review for Cases Identification and Selection}

The Preferred Reporting Items for Systematic Reviews and Meta-Analyses (PRISMA) guidelines [24] were employed for the systematic identification and assessment of cases, as illustrated in Figure 1. Four steps were followed: 1 . Record identification, 2. Record screening, 3. Eligibility assessment, and 4. Inclusion of studies.
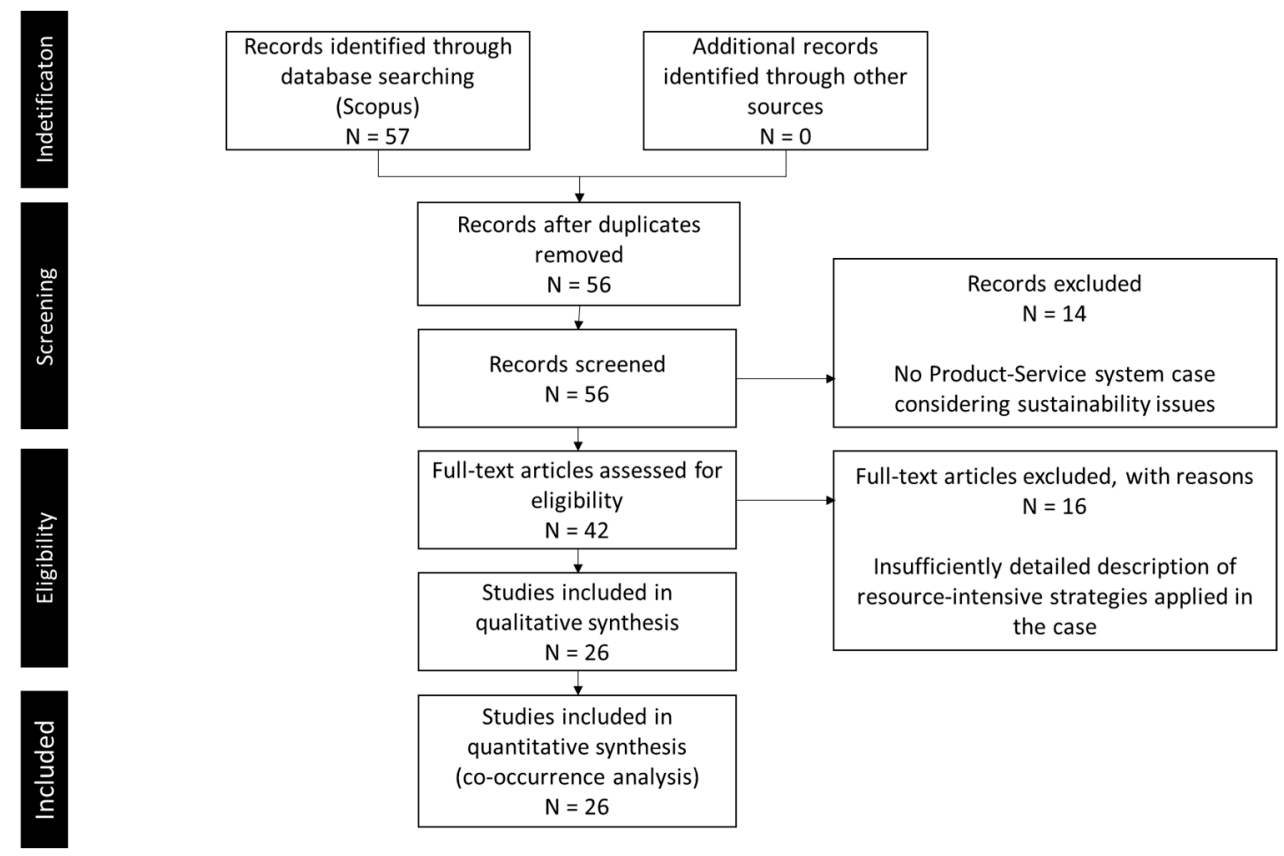

Figure 1. Information flow through systematic review steps employed. 
During records identification, the PSS research field was targeted. It is a relatively mature research area, in which the BM structure plays a central role to enable potentially circular solutions and which can contribute to the purpose of this research. Additionally, there is an increasing corpus of PSS cases in the literature, which can be used as secondary sources to investigate through the CE lens. The review sought journal articles in the Scopus research database in English that describe case applications and discuss the sustainability aspects of PSS solutions from 2009 to 2018.

The selection of articles was performed based on a string which combined keywords to identify PSS case studies discussing environmental, social, and economic aspects, impacts, and benefits. The following string was applied: TITLE-ABS-KEY ("case" OR "real case" OR "real application" OR "case application" OR "case study" OR "case research") AND TITLE-ABS-KEY ("PSS" OR "Product-service system") AND (("environmental aspects" OR "environmental impacts" OR "environmental benefits") OR ("social aspects" OR "social impacts" OR "social benefits") OR ("economic aspects" OR "economic impacts" OR "economic benefits")).

Fifty-six articles were considered after duplicates were removed. Then, a first filter was applied by reviewing the abstracts to screen articles, which indeed presented PSS cases and discussed sustainability aspects, resulting in 42 articles.

Next, for the eligibility assessment, the introductions, conclusions, and case descriptions were verified to identify whether case descriptions suit the research goal. The primary requirement was the possibility to identify sufficient information about circular strategies. This step resulted in 26 articles eligible for a full verification, which means the exclusion of 16 owing to the lack of focus on the BM perspective or to the inadequate detailing of the solution.

A given article could describe more than one case. Thus, the defined unit of analysis defined for this research is a PSS case. In total, the 26 articles led to the identification of 45 cases, as described in Table 1.

Table 1. PSS case descriptions organized according to industry sectors.

\begin{tabular}{|c|c|c|c|c|}
\hline \multicolumn{5}{|c|}{ Industry Sector } \\
\hline Relat. & PSS Type & $\begin{array}{c}\text { Article-Case \# } \\
\text { (If Two or More Cases) }\end{array}$ & $\begin{array}{l}\text { Case Description-Name or } \\
\text { Provider (If Available) }\end{array}$ & Country/Region \\
\hline \multicolumn{5}{|c|}{ Agriculture } \\
\hline B2B & UO & ([26]-Case 1) & Farming machinery cooperative & Spain \\
\hline B2B & $\mathrm{UO}$ & ([26]-Case 2) & Heifer breeding cooperative & Spain \\
\hline B2B & $\mathrm{UO}$ & ([26]-Case 3) & Fodder provision cooperative & Spain \\
\hline \multicolumn{5}{|c|}{ Built environment } \\
\hline B2B & $\mathrm{PO}$ & [27] & Elevator provision & China \\
\hline $\mathrm{B} 2 \mathrm{~B}$ & $\mathrm{PO}$ & ([28]—Case 2) & Crane-related services & China \\
\hline B2B & $\mathrm{UO}$ & ([29]-Case 3) & Soil compactor provision-Swepac & Sweden \\
\hline B2B & $\mathrm{UO}$ & {$[30]$} & $\begin{array}{l}\text { Monitoring solution for urban } \\
\text { services-Azimut Monitoring }\end{array}$ & France \\
\hline B2B & $\mathrm{RO}$ & ([29]—Case 2) & $\begin{array}{c}\text { Building exteriors cleaning-Qlean } \\
\text { Scandinavia }\end{array}$ & Sweden \\
\hline $\mathrm{B} 2 \mathrm{C}$ & $\mathrm{UO}$ & [31] & $\begin{array}{c}\text { Hybrid energy heating system } \\
\text { provision }\end{array}$ & Australia \\
\hline $\mathrm{B} 2 \mathrm{C}$ & $\mathrm{UO}$ & [32] & Hot water provision & Italy \\
\hline
\end{tabular}


Table 1. Cont.

\begin{tabular}{|c|c|c|c|c|}
\hline \multicolumn{5}{|c|}{ Industry Sector } \\
\hline Relat. & PSS Type & $\begin{array}{c}\text { Article-Case \# } \\
\text { (If Two or More Cases) }\end{array}$ & $\begin{array}{l}\text { Case Description-Name or } \\
\text { Provider (If Available) }\end{array}$ & Country/Region \\
\hline \multicolumn{5}{|c|}{ Clothing } \\
\hline $\mathrm{B} 2 \mathrm{C}$ & $\mathrm{PO}$ & ([33]-Case 3) & $\begin{array}{l}\text { 'Trash design' ECO } \\
\text { WISE-Heidenspass }\end{array}$ & Austria \\
\hline B2C & $\mathrm{PO}$ & ([34]-Case 1) & Clothes lifecycle care-H\&M & Sweden \\
\hline B2C & $\mathrm{PO}$ & ([34]_Case 2) & Clothes lifecycle care-KappAhl & Sweden \\
\hline $\mathrm{B} 2 \mathrm{C}$ & $\mathrm{PO}$ & ([34]-Case 3) & Clothes lifecycle care-Lindex & Sweden \\
\hline $\mathrm{B} 2 \mathrm{C}$ & $\mathrm{PO}$ & ([34]-Case 4) & Clothes lifecycle care-Gina Tricot & Sweden \\
\hline B2C & $\mathrm{PO}$ & ([34]-Case 5) & Clothes lifecycle care-Indiska & Sweden \\
\hline $\mathrm{B} 2 \mathrm{C}$ & $\mathrm{PO}$ & ([34]-Case 6) & Clothes lifecycle care-Boomerang & Sweden \\
\hline B2C & $\mathrm{PO}$ & ([34]—Case 7) & Clothes lifecycle care-Nudie Jeans & Sweden \\
\hline B2C & $\mathrm{UO}$ & ([34]-Case 8) & Clothes rental—Filippa K & Sweden \\
\hline B2C & $\mathrm{UO}$ & ([34]-Case 9) & Clothes rental-UFTD & Sweden \\
\hline \multicolumn{5}{|c|}{ Consumer goods } \\
\hline B2B2C & $\mathrm{UO}$ & [35] & Small household equipment renting & France \\
\hline B2B2C & $\mathrm{RO}$ & [36] & Community drinking water system & Brazil \\
\hline $\mathrm{B} 2 \mathrm{C}$ & $\mathrm{PO}$ & $([33]-$ Case 1) & $\begin{array}{l}\text { Re-use network ECO } \\
\text { WISE-ReVital }\end{array}$ & Austria \\
\hline $\mathrm{B} 2 \mathrm{C}$ & $\mathrm{PO}$ & ([33]-Case 2) & Re-use enterprise ECO WISE-BAN & Austria \\
\hline B2C & $\mathrm{PO}$ & [37] & Keyboard-related services & Iran \\
\hline B2C & $\mathrm{UO}$ & [38] & Water purifier rental & South Korea \\
\hline B2C/B2B & $\mathrm{UO}$ & [39] & Provision of water purifier & Brazil \\
\hline \multicolumn{5}{|c|}{ Industrial machinery } \\
\hline B2B & $\mathrm{PO}$ & {$[40]$} & $\begin{array}{l}\text { Remote maintenance system for } \\
\text { machine tools }\end{array}$ & Greece * \\
\hline B2B & $\mathrm{RO}$ & ([29]—Case 1) & $\begin{array}{l}\text { Paper mill plugs } \\
\text { provision-Polyplank }\end{array}$ & Sweden \\
\hline \multicolumn{5}{|c|}{ Maritime industry } \\
\hline B2B & $\mathrm{RO}$ & $([41]$-Case 1) & Hull cleaning contract & Denmark * \\
\hline B2B & $\mathrm{RO}$ & $([41]$-Case 2) & Steam system audit & Denmark * \\
\hline \multicolumn{5}{|c|}{ Medical devices } \\
\hline B2G & $\mathrm{UO}$ & [42] & $\begin{array}{c}\text { Provision of haemodialysis } \\
\text { equipment }\end{array}$ & Italy * \\
\hline \multicolumn{5}{|c|}{ Mobility } \\
\hline $\mathrm{B} 2 \mathrm{C}$ & $\mathrm{UO}$ & {$[43]$} & Family boats rent for water tourism & Netherlands \\
\hline $\mathrm{B} 2 \mathrm{C}$ & $\mathrm{UO}$ & $([28]$-Case 1) & Car rental & China \\
\hline B2C & $\mathrm{UO}$ & {$[44,45]$} & Car sharing-car2go & Germany \\
\hline $\mathrm{B} 2 \mathrm{C}$ & $\mathrm{UO}$ & [46] & Car sharing-Zipcar & $\begin{array}{l}\text { North America } \\
\text { and Europe }\end{array}$ \\
\hline $\mathrm{B} 2 \mathrm{C}$ & $\mathrm{UO}$ & [47] & Bike sharing—Velo'v & France \\
\hline B2G & $\mathrm{UO}$ & [48] & Bike sharing-Seoul municipality & South Korea \\
\hline
\end{tabular}


Table 1. Cont.

\begin{tabular}{|c|c|c|c|c|}
\hline \multicolumn{5}{|c|}{ Industry Sector } \\
\hline Relat. & PSS Type & $\begin{array}{c}\text { Article-Case \# } \\
\text { (If Two or More Cases) }\end{array}$ & $\begin{array}{l}\text { Case Description-Name or } \\
\text { Provider (If Available) }\end{array}$ & Country/Region \\
\hline \multicolumn{5}{|c|}{ Oil, gas, and mining } \\
\hline B2B & $\mathrm{UO}$ & ([49]-Case 1) & $\begin{array}{l}\text { Air separation equipment } \\
\text { provision-Hangyang Co. }\end{array}$ & China \\
\hline B2B & $\mathrm{UO}$ & {$[50]$} & Truck tires as a service & Chile \\
\hline B2B & $\mathrm{RO}$ & ([49]-Case 2) & Oxygen provision-Hangyang Co. & China \\
\hline \multicolumn{5}{|c|}{ Waste management } \\
\hline B2G & $\mathrm{PO}$ & ([51]-Case 1) & $\begin{array}{c}\text { Waste-to-energy systems-Usitall } \\
\text { AB }\end{array}$ & Sweden \\
\hline $\mathrm{B} 2 \mathrm{G}$ & $\mathrm{PO}$ & ([51]-Case 3) & $\begin{array}{l}\text { Waste-to-energy and recycling } \\
\text { systems_-VafabMiljo }\end{array}$ & Sweden \\
\hline $\mathrm{B} 2 \mathrm{G} / \mathrm{B} 2 \mathrm{~B}$ & $\mathrm{PO}$ & ([51]-Case 2) & $\begin{array}{l}\text { Biogas production-Swedish Biogas } \\
\text { International }\end{array}$ & Sweden \\
\hline B2G/B2B & $\mathrm{RO}$ & ([51]—Case 4) & $\begin{array}{c}\text { Biogas-related solutions-Svensk } \\
\text { Biogas }\end{array}$ & Sweden \\
\hline
\end{tabular}

The asterisk symbol $\left({ }^{*}\right)$ indicates cases which the country or region was inferred based on the authors' location.

The cases were then grouped into sectors, such as mobility, agriculture, clothing, and others. The solutions stemmed from several provider-customer relationships, covering the traditional B2B (business to business), B2C (business to customers) and B2G (business to government) relationships, as well as more elaborate ones such as B2B2C (business to business to customers). Additionally, the product and service bundles were investigated to consolidate the PSS cases into product-oriented, use-oriented, and result-oriented, according to Tukker [52]. For cases which the PSS type was not reported, the type was inferred based on the description of the case presented in the article. A code was assigned for each case, considering the authors, year of publication, and a number when a given source described more than one case. Lastly, the country or region of the study was identified based on the description provided in the article or inferred based on the authors' location—an asterisk symbol is used to indicate such cases.

\subsection{Content Analysis of Identified Cases}

A deductive approach can provide insights concerning the relationship among variables, helping to refine the initial scheme and to deepen the knowledge of how these relate [53]. Deductive content analysis was used to characterize cases, identify the occurrence of circular strategies in the set of cases, and to elicit strategy operationalization practices from the know-how contained in the case descriptions. Three steps were followed: 1 . Code system definition, 2. Content analysis of segments following the code system, and 3. Analysis and synthesis of results. The professional MAXQDA ${ }^{\circledR}$ software enabled several iterations of analysis to achieve consensus and enhance its quality. Each segment coded was analyzed at least two times following the procedures for strategy identification and practice elicitation-once when the case was thoroughly reviewed, and again when cross-checking each code among cases.

A coding system was developed for case characterization and for circular strategy identification. The code system consists of two types of tags, as shown in Figure 2. PSS solution tags were used to characterize each PSS case, by identifying the descriptions of the products, associated services, required infrastructure, and stakeholders involved. The PSS solution description coding led to the characterization presented in Table 1. 


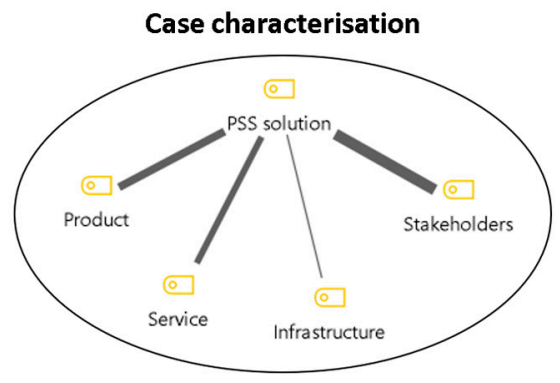

Evidence of circular strategy
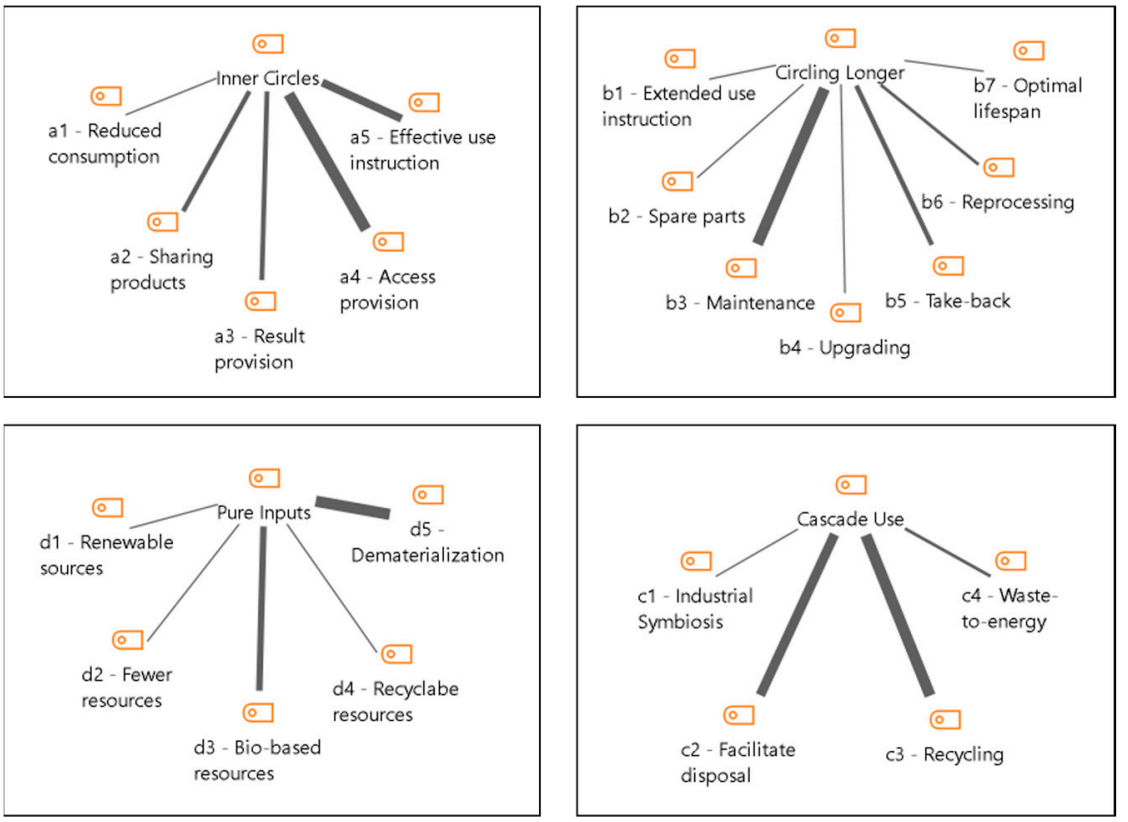

Figure 2. Coding system applied in this research.

The well-known classifications of circular BMs from the CE literature are the sources for circular strategy tags. The codes were elicited from the circular BM classifications available in the literature, including academic research $[4,54-56]$ and reports and books from non-governmental organizations and consultancies $[57,58]$. The descriptions of BM types and available examples were used to elicit the circular strategies used in this research. The CE sources of value creation developed by the Ellen MacArthur Foundation [57] were used to organize the circular strategies, because it is a well-known classification system in CE research and practice [3], and matches the adopted resource-effectiveness rationale. The descriptions were provided for each of the circular strategies. For example, within circling longer, one strategy is called maintenance, which was described as follows: "Provide or facilitate failure prediction, maintenance, and/or repairing services". Each of the 21 strategies was available in more than one considered classification from the literature.

In the content analysis step, the code system was used to categorize segments whenever the meaning of a given code was recognized, i.e., a text or image that characterized the PSS case or indicated a circular strategy application. As an example, the following segment, "For the rental model, the service provider periodically visits customers' residences to provide maintenance services" [38], was recognized as evidence of the application of maintenance and was therefore tagged. Evidence of circular strategies led to identifying two to nine different strategies per case.

During the analysis and synthesis of results, compiling the data into matrices enabled verifying whether their applications differed among product-oriented, use-oriented, or result-oriented solutions. Association mapping using the Jaccard index [59] was applied to seek synergies among strategies and classes of strategies. This index is given by the quotient between the number of times that pairs of 
strategies or classes of strategies were concomitantly applied relative to the total number of times that at least one of them occurs in the sample. The higher the value of this index, the more compatible are these pairs.

An adaption of the BM canvas [60] was used to catalogue practices for circular strategy operationalization based on know-how available in cases-see Table 2. Practices were identified in three domains of the canvas, namely the providers, product, and customer domains. Each considered dimension was adopted to identify the operational issues of strategy application aligned to the resource-effectiveness goal of the classes of circular strategies from the considered list of cases. In total, 77 practices were identified in the considered set of sustainability-oriented PSS cases.

Table 2. Protocol to elicit practices for operationalization of circular strategies for enhanced resource-effectiveness considering the $\mathrm{BM}$ dimensions.

\begin{tabular}{|c|c|c|c|c|}
\hline \multicolumn{2}{|c|}{ Providers Domain } & $\begin{array}{l}\text { Product Domain } \\
\text { Product Features }\end{array}$ & \multicolumn{2}{|c|}{ Customers Domain } \\
\hline $\begin{array}{l}\text { Key Partners } \\
\text { With whom and how } \\
\text { to cooperate in } \\
\text { providing a solution } \\
\text { that enhances } \\
\text { resource-effectiveness? }\end{array}$ & $\begin{array}{l}\text { What do we need to do } \\
\text { to produce, market, } \\
\text { and distribute a } \\
\text { solution that enhances } \\
\text { resource-effectiveness? }\end{array}$ & $\begin{array}{l}\text { What do we need to } \\
\text { change in the physical } \\
\text { product to enable a } \\
\text { solution that enhances } \\
\text { resource-effectiveness? }\end{array}$ & $\begin{array}{l}\text { Customer } \\
\text { Relationships } \\
\text { How should we } \\
\text { communicate and } \\
\text { connect to our market } \\
\text { to enable a solution } \\
\text { that enhances } \\
\text { resource-effectiveness? }\end{array}$ & $\begin{array}{l}\text { Channels } \\
\text { How should we reach } \\
\text { and deliver our } \\
\text { solution to our market } \\
\text { to enhance } \\
\text { resource-effectiveness? }\end{array}$ \\
\hline
\end{tabular}

The segments comprising a given strategy were analyzed using the protocol to elicit practices to operationalize circular strategies considering the specific BM domain and BM dimension that demanded adaptation. For instance, to operationalize maintenance, it was identified that the following recurrent practices "elaborate clear rules and contracts for maintenance-e.g., define product and part conditions, frequencies, and responsibilities", which defines a required adaptation on the customer relationships for operationalization.

Given the multi-perspective analysis, comprising classes of strategies, strategies, and practices for operationalization, a framework was developed to organize this knowledge.

\section{Circular Innovation Framework: Bridging Concept to Practice}

The proposed framework for circular innovation is composed of three perspectives: Conceptual, strategic, and practical. Figure 3 shows the theoretical representation. The three perspectives constitute the essential abstraction scales to envision, implement, and operationalize circular solutions. From the conceptual to practical perspectives, the rationale becomes more specific with respect to how circularity can be achieved when combining products and services. The discussion deepens to-how to achieve circularity? From the practical to conceptual level, the question arises of which resource cycle is enabled by a specific strategy-practice combination-what resource to circularize? Following the rationale enabled by the framework, the three abstraction scales are connected to envision and operationalize circular BMI. 


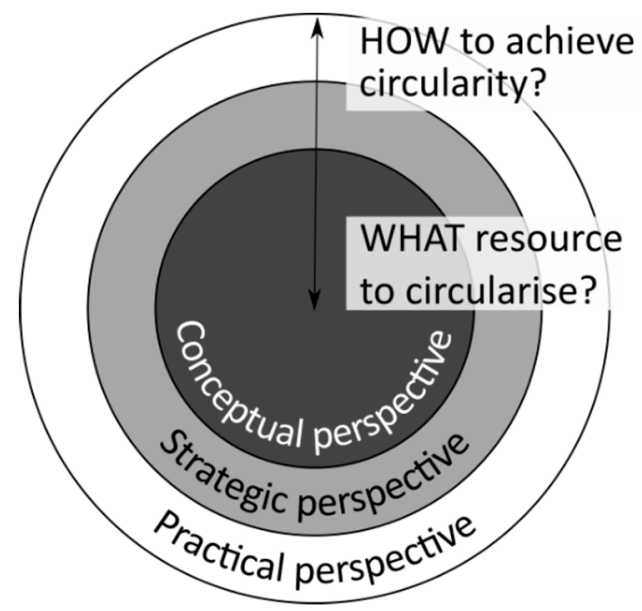

Figure 3. A theoretical representation of the circular innovation framework composed of conceptual, strategic, and practical perspectives.

In the conceptual perspective, a resource-efficiency logic is followed. Two main characteristics are central to organize the initiatives to close the loop of resources: Conservation of the embodied energy in artefacts and prioritization of skilled labor through services, instead of further material and energy utilization. Regarding closed industrial systems, humans act as the stabilizing component that defines the demand for products, and that can bring products back as input through labor [61]. When prioritizing manners to bring back input to the system, King et al. [62] argue that emergy-i.e., the embodied energy preserved when providing further lifetime to resources-is a critical criterion, and should be maximized. The smaller the loop, the less energy is necessary to recover a given product according to the laws of thermodynamics [62]. In other words, in general, preventing a given artefact from breaking is a less resource-intensive endeavor than repairing it, because more embodied energy (or emergy) is maintained. Consequently, repairing is likely preferable to recycling the material and manufacturing it again. Furthermore, "the smaller the loop, the more profitable it is" [63], which means that utilization-focused strategies lead to more value generated per resource use in comparison to other strategies, because they are more labor-intensive initiatives. In sum, circular strategies should be prioritized according to the existing conditions of resources and labor, aiming for the effective use of resources.

Resources exist at different aggregation levels in any industrial system and are connected to specific recovery strategies [64], e.g., repairing occurs at the product level, remanufacturing at the parts level, and recycling at the material level. Table 3 arranges the classes of perspectives contained in the circular BM classifications according to the conceptual perspective of the circular innovation framework, following the resource-effectiveness logic. Each class of strategy is categorized according to the extent to which it: (1) Enhances the level of use and consumption of products in the inner circles; (2) enhances the lifetime of products, parts, and components when circling longer; (3) recovers discarded materials and energy through cascade use; and (4) enhances the application of materials and energy through pure inputs. Examining the effective use of products, components, materials, and energy enables a systemic examination towards improved impacts.

Types with similar names are positioned differently in the analysis, e.g., extending product value in Bocken et al. [4] and Moreno et al. [55] do not lead to similar resource-effectiveness. Table 3 shows that certain classifications do not present strategies for enhanced use of materials and energy. Additionally, at such an aggregate level, the types available in the literature comprise different approaches to create and deliver circular value. For instance, maintenance, product upgrading, and remanufacturing are commonly jointly presented. Thus, it may not be clear-cut as to whether a given class contains a specific strategy. Although a conceptual perspective enables a sound understanding of the better application of resources, more concrete plans of action are needed. 
Table 3. Circular business model classifications organized according to the conceptual perspective of the circular innovation framework.

\begin{tabular}{|c|c|c|c|c|}
\hline \multirow[b]{2}{*}{$\begin{array}{c}\text { CBM } \\
\text { Classification }\end{array}$} & \multicolumn{4}{|c|}{ Resource Effectiveness } \\
\hline & $\begin{array}{c}\text { Enhance the Level of Use } \\
\text { and Consumption } \\
\text { of Products }\end{array}$ & $\begin{array}{l}\text { Enhance the Lifetime of } \\
\text { Products, Parts, } \\
\text { and Components }\end{array}$ & $\begin{array}{c}\text { Recover Discarded Materials } \\
\text { and Energy }\end{array}$ & $\begin{array}{c}\text { Enhance the } \\
\text { Application of } \\
\text { Materials and Energy }\end{array}$ \\
\hline $\begin{array}{l}\text { Sources of value } \\
\text { creation [57] }\end{array}$ & - Inner circles & Circling longer & Circling 1Cascade use & Pure inputs \\
\hline $\begin{array}{l}\text { BMs for circular } \\
\text { growth [58] }\end{array}$ & $\begin{array}{ll}\text { - } & \text { Sharing platform } \\
\text { - } & \text { Product as a service }\end{array}$ & Product life-extensior & Recovery \& Recycling & $\begin{array}{l}\text { - Circular } \\
\text { supply chain }\end{array}$ \\
\hline BMI in a CE [56] & $\begin{array}{ll}\text { - } & \text { Access model } \\
\text { - } & \text { Performance model }\end{array}$ & $\begin{array}{ll}- & \text { Upgrading } \\
- & \text { Remanufacturing } \\
- & \text { Hybrid model } \\
- & \text { Reuse }\end{array}$ & $\begin{array}{ll}- & \text { Product recycling } \\
- & \text { Product transformation } \\
- & \text { Energy recovery }\end{array}$ & - \\
\hline $\begin{array}{l}\text { Circular BM } \\
\text { strategies [4] }\end{array}$ & $\begin{array}{ll}\text { - } & \text { Access and } \\
& \text { performance model } \\
\text { - } & \text { Encourage sufficiency }\end{array}$ & $\begin{array}{ll}\text { - } & \text { Extending } \\
& \text { product value } \\
\text { - } & \text { Classic long life }\end{array}$ & $\begin{array}{ll}\text { - } & \text { Extending } \\
& \text { resource value } \\
\text { - } & \text { Industrial symbiosis }\end{array}$ & - \\
\hline $\begin{array}{c}\text { Circular BM Types } \\
{[54]}\end{array}$ & $\begin{array}{ll}\text { - } & \text { Share } \\
\text { - } & \text { Optimize }\end{array}$ & Loop & Regenerate & $\begin{array}{ll}\text { - } & \text { Virtualise } \\
\text { - } & \text { Exchange }\end{array}$ \\
\hline $\begin{array}{c}\text { Circular BM } \\
\text { archetypes [55] }\end{array}$ & $\begin{array}{ll}- & \text { Sharing platforms } \\
- & \text { Extending } \\
\text { product value }\end{array}$ & $\begin{array}{ll}\text { - } & \text { Product } \\
& \text { life extension }\end{array}$ & Resource value & Circular supplies \\
\hline
\end{tabular}

The strategic perspective is constituted by defined schemes to enact enhanced resource-effectiveness. Figure 4 displays a detailed representation of the circular innovation framework, in which the strategic perspective is thoroughly detailed. This level is constituted by 21 clearly defined strategies that can be applied to guide further development of circular BMs and the investigation of the alignment of existing solutions. Each strategy is positioned according to the extent to which it enhances resource-effectiveness. In the figure, the conceptual to practical rationale is represented by the theoretical model illustrated in the top-right corner.

Finally, the practical perspective is integrated into the framework as the manner to operationalize the strategies. It consists of BM adaptations, i.e., adjustments in the value logic that enable the application of circular strategies. This perspective comprises adjustments in the suppliers' structure, connection to customers, and product features. This multi-perspective framework is the guiding thread to report and discuss the results throughout this research.

The investigation applying the circular innovation framework in the identified sustainability-oriented PSS cases is further presented in two ways. First, following a practical to conceptual approach, operational practices that enable circular strategies are described. Next, the occurrence and co-occurrence of circular strategies within the set of cases clarify the frequency of application of strategies within each type of PSS and demonstrate the combined use of strategies that potentialize the expected resource-effectiveness of circular solutions. 


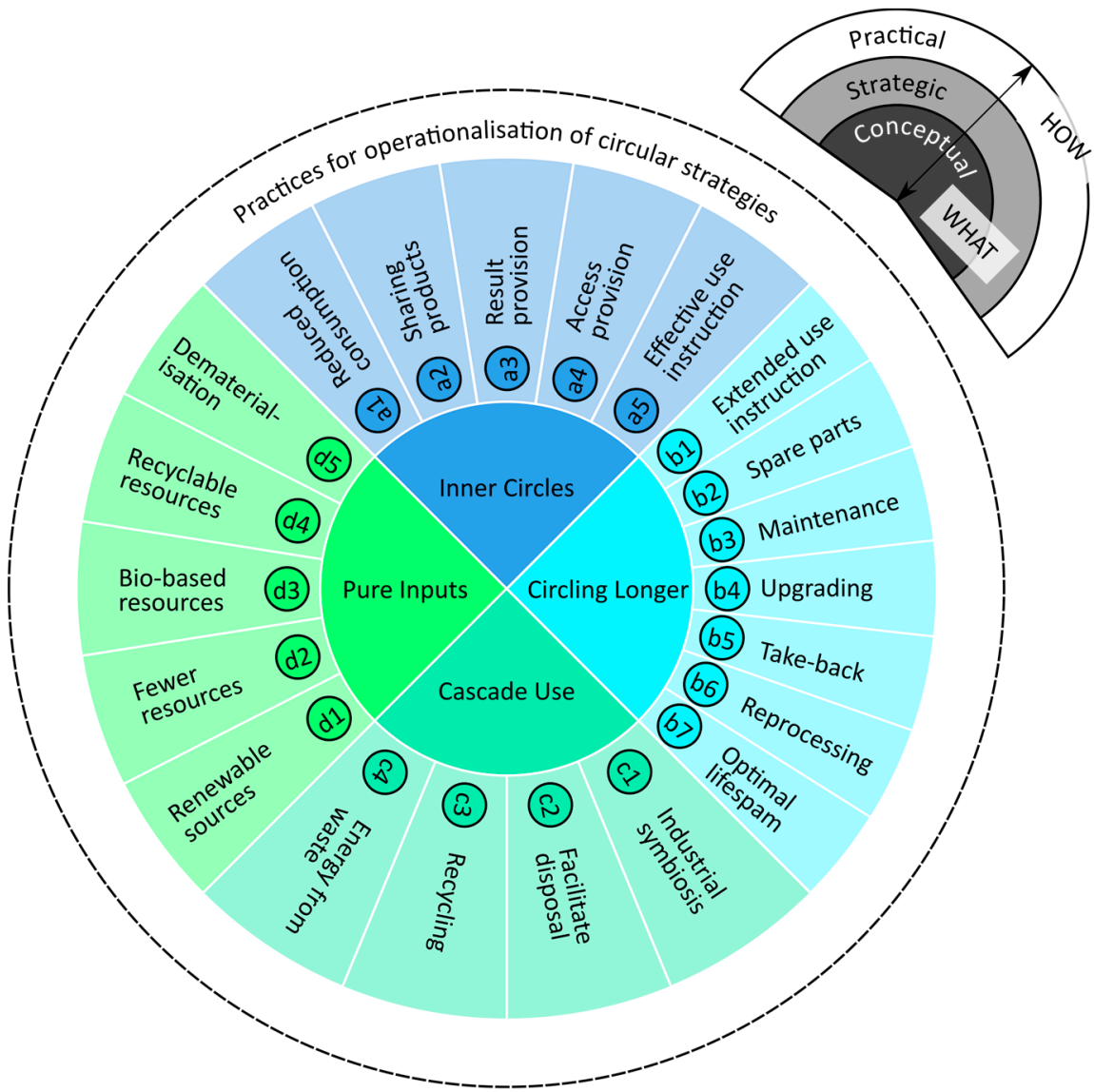

\begin{tabular}{|c|c|}
\hline \multicolumn{2}{|c|}{ Circular strategies description } \\
\hline $\begin{array}{l}\text { Inner Circles } \\
\text { Strategies for enhanced level of use and consumption of products } \\
\text { (a1) Encourage reducing end-user consumption } \\
\text { (a2) Enable shared use or ownership of products among members of } \\
\text { a community } \\
\text { (a3) revidaining ownership } \\
\text { (a4) Sell access to a product for a specific period or use cycles, while } \\
\text { (a5) Knowledge-based services to increase the level of use of } \\
\text { pure Incts } \\
\text { Strategies to enhance the application of materials and energy } \\
\text { (d1) Use of renewable energy for products and components } \\
\text { (d2) Use of fewer resounufacturing and functioning } \\
\text { (d3) Use of bio-based input material for products or components } \\
\text { production } \\
\text { (d4) Use of fully recyclable input material for products or } \\
\text { (d5) Provide the function of products and services through virtual or } \\
\text { disruptive manners }\end{array}$ & $\begin{array}{l}\text { Circling Longer } \\
\text { Strategies for enhanced lifetime of products, parts and components } \\
\text { (b1) Knowledge-based services to increase the lifetime of products } \\
\text { or components } \\
\text { (b2) Provide spare and consumable parts while keeping longer } \\
\text { lifecycle parts } \\
\text { b3 Provide or facilitate failure prediction, maintenance or repair } \\
\text { (b4) Upgrade system while keeping functional products' subsystems } \\
\text { or components } \\
\text { b5) Facilitate sales, return or collection of used units of functional } \\
\text { products or components } \\
\text { (b6) Provide reconditioning, refurbishing, or remanufacturing } \\
\text { (b7) Manufacture products or components with an optimal lifespan } \\
\text { Cascade Use } \\
\text { Strategies to recover discarded materials and energy } \\
\text { (c1) Use of a process' by-products as input to another process } \\
\text { (c2) Facilitate sales, return or collection of discarded material } \\
\text { (c3) Recover resources out of discarded material through recycling, } \\
\text { upcycling, downcycling, or biodegradation } \\
\text { (C4) Recover energy out of discarded material through heat, }\end{array}$ \\
\hline
\end{tabular}

Figure 4. A detailed representation of the circular innovation framework containing the description of circular strategies.

\section{Practices for the Operationalization of Circular Strategies}

The knowledge obtained from recognized PSS cases assists in representing the business rationale required from the conceptualization to operation of circular strategies. The specific application of strategies in the literature guides the description of tactical choices made with respect to the providers, product, and customers domains for each of the four conceptual forms to achieve enhanced 
resource-effectiveness: In the inner circles, for circling longer, through cascade use, and through pure inputs.

\subsection{Practices for Operationalization of Circular Strategies in the Inner Circle}

To enhance resource-effectiveness in the inner circles, the level of use of durables and consumables needs to be aligned to the business logic. Table 4 presents the practices for the five circular strategies that enable the inner circles. In total, 24 practices were identified. Most practices are related to the customer relationships and key partners to enable a1-Reduced consumption, a2-Sharing products, a3-Result provision, a4-Access provision, and a5-Effective use instruction.

Three practices enable a1-Reduced consumption. Governments and NGOs may be faced as key partners to raise awareness of wasteful practices of consumption, thereby creating a new type of customer relationship. In the water purifier provision case [39], this practice was used to motivate bars and restaurants to substitute the provision of bottled water with filtered water. Additionally, designing products such that customers desire to buy products less often is a significant change in the product feature. One brand, Filippa $\mathrm{K}$, focused on designing and manufacturing vintage-style clothes rather than fast-fashion trends " ... by creating timeless pieces and wardrobe favourites that can be used season after season" [34]. Finally, providing incentives to influence clients towards more sustainable options is a robust manner of changing customer relationships. In the Zipcar car sharing case, incentives were provided for users to rent electric cars [46].

To enable a2-Sharing products, six practices were identified. A critical aspect regards setting up physical or digital means to allow collective access to products. The cases of Amaya et al. [47] and Catulli et al. [46] respectively describe setting up bike stations and exclusive parking spaces. Firnkorn and Müller [44,45] present the possibilities of free-floating car-sharing, thereby eliminating the need for physical stations by using a GPS feature of the product. In some cases, an intermediate distribution partner facilitates access to products, as presented by the two B2B2C cases-commercial establishments are intermediate distribution partners in the community drinking water system [36], and suburban supermarkets are stations for household equipment renting [35]. Using an online platform to facilitate selecting, locating, collecting, and retrieving shareable products is described in three cases [35,44-46]. A particular implementation of sharing products stems from the cases presented by Pereira et al. [26]. In the three cases, the collective ownership of infrastructure for farm cooperatives enables mutual benefits.

Four practices help to operationalize a3-Result provision. This strategy implies selling the product functionality, the result achieved through the product use, or even charging the customer according to the achieved product performance. Regardless of the type of offer, the responsibility of the asset moves to the providers' domain. Risk and responsibility sharing was deemed crucial to enable hull cleaning services ([41]—Case 1). Service providers shared the responsibilities for customer services and the benefits of profits from the provision of water by volume [36]. Within the product domain, Peruzzini and Germani present the possibility of remotely monitoring a condensing boiler to verify its performance and enhance service provision. Finally, in the customers domain, clear rules and contracts are described in four cases as central features to enable result provision ([27,32,41]—Case 1, [51]—Case 4). Specific rules by which the service level was coupled to the use of resources were identified. A performance threshold considering fuel use was applied to optimize hull cleaning services ([41]—Case 1), fuel consumption improvement was an input of the final price of auditing services ([41] — Case 2), and the actual energy used to operate elevators was a variable in a performance contract [27]. In all three cases, the implication of fewer resources used leading to lower costs for customers was integrated into the relationship maintained with customers and empowered circularity. 
Table 4. Practices for operationalization of circular strategies in the inner circles positioned according to the considered BM dimensions.

\begin{tabular}{|c|c|c|c|c|}
\hline \multicolumn{2}{|c|}{ Providers Domain } & \multirow{2}{*}{\begin{tabular}{l}
\multicolumn{1}{c}{ Product Domain } \\
Product Features \\
What do we need to change in the \\
physical product to enable \\
a solution that enhances the level of \\
use and consumption of products?
\end{tabular}} & \multicolumn{2}{|c|}{ Customers Domain } \\
\hline $\begin{array}{l}\text { Key Partners } \\
\text { With whom and how to cooperate } \\
\text { in providing a solution that } \\
\text { enhances the level of use and } \\
\text { consumption of products? }\end{array}$ & $\begin{array}{l}\text { Key Activities } \\
\text { What do we need to do to produce, } \\
\text { market, and distribute a solution } \\
\text { that enhances the level of use and } \\
\text { consumption of products? }\end{array}$ & & $\begin{array}{l}\text { Customer Relationships } \\
\text { How should we communicate and } \\
\text { connect to our market to enable } \\
\text { a solution that enhances the level of use } \\
\text { and consumption of products? }\end{array}$ & $\begin{array}{l}\text { Channels } \\
\text { How should we reach and deliver } \\
\text { our solution to our market to } \\
\text { enhance the level of use and } \\
\text { consumption of products? }\end{array}$ \\
\hline \multirow{2}{*}{$\begin{array}{l}\text { P1 (a1)_Partner with } \\
\text { governments or NGOs to raise } \\
\text { awareness of customers about } \\
\text { wasteful practices of consumption } \\
\text { P4 (a2)_Set up intermediate } \\
\text { distribution partners to facilitate } \\
\text { access to shared products } \\
\text { P5 (a2)_Facilitate collective } \\
\text { ownership of infrastructure for } \\
\text { mutual and local use } \\
\text { P10 (a3)_Facilitate risk and } \\
\text { responsibility sharing among } \\
\text { manufacturer and } \\
\text { service providers } \\
\text { P14 (a4)-Facilitate risk and } \\
\text { responsibility sharing among } \\
\text { manufacturer and } \\
\text { service providers }\end{array}$} & $\begin{array}{l}\text { P7 (a2)—Consistently track and } \\
\text { relocate shareable products among } \\
\text { stations to facilitate } \\
\text { shared distribution } \\
\text { P19 (a5)—Identify and facilitate } \\
\text { clients' process optimisation } \\
\text { through consulting, auditing, } \\
\text { or training } \\
\text { P20 (a5)-Provide installation } \\
\text { service to ensure performance }\end{array}$ & \multirow[t]{2}{*}{$\begin{array}{l}\text { P2 (a1)—Apply design for } \\
\text { attachment so that customers desire } \\
\text { products less often, e.g., classic style } \\
\text { clothes } \\
\text { P7 (a2)—[see Key Activities] } \\
\text { P8 (a2)—Use IoT solutions to enable } \\
\text { sharing without the need for } \\
\text { physical stations } \\
\text { P11 (a3)-Enable remote } \\
\text { monitoring of product functionality } \\
\text { or performance to guarantee } \\
\text { service provision }\end{array}$} & \multirow{2}{*}{$\begin{array}{l}\text { P1 (a1)_[see Key Partners] } \\
\text { P3 (a1)_Provide incentives for clients } \\
\text { to use or acquire more } \\
\text { sustainable options } \\
\text { P12 (a3)—Elaborate clear rules and } \\
\text { contracts to clarify expected function } \\
\text { or performance } \\
\text { P13 (a3)—Elaborate rules for service } \\
\text { provision that minimise the use of } \\
\text { resources while maintaining } \\
\text { customers' satisfaction } \\
\text { P15 (a4)—Elaborate service fees and } \\
\text { conditions considering length or cycles } \\
\text { of product use that are competitive } \\
\text { with ownership-based offers } \\
\text { P16 (a4)—Offer different service levels } \\
\text { for customers to choose from } \\
\text { P17 (a4)—Create incentives } \\
\text { (e.g., decreased fees) for clients that } \\
\text { enable longer lifetimes of products } \\
\text { P21 (a5)—Provide knowledge to } \\
\text { consumers for improved experience } \\
\text { and energy-saving behaviour }\end{array}$} & \multirow[t]{2}{*}{$\begin{array}{l}\text { P9 (a2)_Develop online platform } \\
\text { to facilitate selecting, locating, } \\
\text { collecting, and retrieving } \\
\text { shareable products } \\
\text { P18 (a4)-Develop an online } \\
\text { platform to enable service } \\
\text { provision from the use of products } \\
\text { P22 (a5)—Develop a web-based } \\
\text { platform to facilitate access } \\
\text { to instructions }\end{array}$} \\
\hline & $\begin{array}{l}\text { Key Resources } \\
\text { What are the main assets we need to } \\
\text { have to produce, market, and distribute } \\
\text { a solution that enhances the level of use } \\
\text { and consumption of products? }\end{array}$ & & & \\
\hline
\end{tabular}


Five practices enable a4-Access provision. The responsibility for the asset moves to the providers' domain in this strategy as well. The practice of sharing risks and responsibilities among providers was observed in a few cases. In the case presented by Allais and Gobert [35], the Original Equipment Manufacturer - OEM and supermarkets share operational risks in renting small household equipment, once the latter is responsible for customer-related operations (i.e., to deliver, control, repair, and collect products). Within the customers' domain, transparent service fees and conditions to enable the relationship with customers are described in six cases ([34]—Cases 8 and $9[35,43-45,47])$. In fact, fees can be used to encourage customers to enhance the lifetime of products. In the truck tires as a service case presented in Pascual et al. [50], a tool helps to calculate contract fees according to tire lifetime - rental rates for truck tires diminish as the product life increases. Finally, different service levels for customers to choose and online platforms to enable service provision can be implemented to enable access provision operationalization.

The provisioning of knowledge-based services to increase the level of use of products (a5-Effective use instruction) is enabled by four practices. Within B2B markets, a central practice is to identify and facilitate clients' process optimization. This practice is critical in the two maritime industry cases presented by Pagoropoulos et al. [41]: First, guidance is offered in a hull cleaning contract for optimal painting selection and application to improve ships' fuel efficiency (Case 1); second, an auditing service is offered to improve the fuel efficiency of steam systems (Case 2). In Pereira et al. [26], three farming cooperatives take advantage of the proximity to the cooperative members to offer knowledge-based services through consulting and optimization services.

In B2C markets, instructing users are critical to influencing their behavior towards the improved use of resources. Knowledge is provided to consumers for improved experience and energy-saving behavior in a few clothes industry cases described by Stål and Jansson [34]. Washing advice is provided by three brands to induce improved energy and water use during the clothes' lifetime through washing using colder water and by not using a drying machine. Additionally, Nudie Jeans provides advice to wash jeans less frequently while improving the break-in experience. In the water purifier rental case, users are encouraged to reduce the energy consumption of the fleet of water purifiers by turning off their devices when they are not consuming water from them [38]. Developing online platforms to facilitate access to instructions can also help to shape customers' behavior. In the boat rental case [43], an online platform was developed to provide waterway maps, information on interesting natural points, and the location of nearby stores to customers. Through effective use instruction, customer experience is potentially expanded while reducing the use of resources (e.g., energy, water, fuel). While customer experience is central to enabling improved behavior through knowledge-based services in a B2C setting, process optimization drives this strategy in the B2B markets.

\subsection{Practices for the Operationalization of Circular Strategies for Circling Longer}

To enhance resource-effectiveness for circling longer, the increased lifetime of products, parts, and components need to be aligned to the business logic. Table 5 presents the practices for the seven circular strategies that enable circling longer. In total, 30 practices were identified. Most practices are related to customer relationships and the product features to enable b1-Extended use instruction, b2-Spare parts, b3-Maintenance, b4-Upgrading, b5-Take-back, b6-Reprocessing, and b7-Optimal lifespan.

Six identified practices enable the b1-Extended use instruction strategy. This strategy uses knowledge-based services, aiming to improve the lifetime of products or components. Empowering service providers through training is a recognized practice to enable this strategy on the providers' side. In the soil compactor provision case, the manufacturers enable rental firms to carry out restoration activities and reduce the need to transport the devices back to the factory ([29]-Case 3). On the customer side, sharing strategic information is critical. Knowledge can be provided to customers to disseminate desirable behavior in the $\mathrm{B} 2 \mathrm{C}$ market. In the water purifier rental case, every time an employee of the water purifier provider visited customers, they provided information to maintain the water purifier under satisfactory conditions [38]. One of the re-use network of stores, BAN, teaches 
courses at the local university to raise awareness about the re-use of products ([33] —Case 2). Similarly, in B2B settings, trust relationships among manufacturers, service providers, and clients are required. Pagoropoulos et al. ([41]—Case 1) describe the provision of cleaning guidelines and the indication of reliable cleaning firms by the hull painting provider to clients, whenever necessary, to optimize the painting's lifetime. Fargnoli et al. [42] describe training services in hospitals to avoid the improper use of haemodialysers, avoiding preventable failures. In both B2B and B2C settings, this type of information sharing among stakeholders advances the common goal of increasing the lifetime of products.

The provision of Spare parts (b2) while maintaining functional parts is supported by two practices. A key activity is to consider the lifecycles of products and parts for replacement separately. In the water purifier rental case, four filters of the water purifier rental case exist to perform specific functions and are replaced accordingly to enhance the water quality and product life [38]. The same applies to the haemodialyser case, in which planned replacement interventions follow part lifetimes [42]. Moreover, paper plugs, which are consumables of the system used for paper transport, are replaced by the manufacturer after component exhaustion ([29] - Case 1). On the customers' side, facilitating the selection and acquisition of spare parts is an identified practice. A one-stop spare parts supply is provided in the elevator provision case [27], reducing the need to deal with different suppliers. In sum, while there are opportunities to develop consumables with improved lifespan, the chances of disposing of still-functioning products are potentially reduced by effectively replacing the consumables.

Maintenance (b3) is enabled by seven practices. This strategy comprises predictive, preventive, and corrective maintenance. On the supplier side, the distribution structure of maintenance centers is critical for strategy operationalization. In the bike-sharing case [47], investing in a decentralized set of smaller maintenance stations was considered more suitable than a larger center. When infrastructure is already available, establishing partnerships for a maintenance provision is an option, as in the household appliance renting case in which partner supermarkets maintain products [35], and the water purifier rental case in which a service provider is responsible for bimonthly filter maintenance [38]. A partnership may occur by sharing knowledge for maintenance, as in Polyplank's paper mill plug provision case or in Swepac's provision of soil compactors ([29]—Cases 1 and 3).

Changes in the product domain are also central for a maintenance provision. Remote monitoring of heaters is described in Peruzzini and Germani [32]. Mourtzis et al. [40] describe a monitoring system used to assess the probability of failure of industrial machines, and when the probability is high, it activates an augmented reality remote system for condition-based maintenance. The system is also capable of checking broken machines and activating the remote maintenance system for corrective maintenance [40]. This last case comprises two practices: 1 . Enable remote monitoring of product to enable condition-based maintenance and 2. Enable remote maintenance of products through virtual reality.

In the customers' domain, clear rules and contracts for maintenance are critical. For predictive maintenance, which relies on the probability of failure, the hull cleaning solution ([41]—Case 1) exemplifies a case of maintenance activated when a pre-established performance threshold is exceeded, promoting performance and lifetime. In preventive maintenance cases, frequencies and events need to be well-defined. In the water purifier case, maintenance happens twice a year [39]; elevator maintenance is conducted twice a month [27]; maintenance of water purification systems occur weekly [36]; and daily maintenance of facilities, machinery, and tools is described by Pereira et al. ([26]—Case 1). Fargnoli et al. [42] present a detailed maintenance schedule for different components of the haemodialyser based on hours of product use. Finally, providing repair kits for consumers is an identified practice which combines a new product feature and modifies the customer relationship structure. The free jeans repair kits described by Stål and Jansson ([34]—Case 1) exemplify this practice. 
Table 5. Practices for the operationalization of circular strategies for circling longer positioned according to the considered BM dimensions.

\begin{tabular}{|c|c|c|c|c|}
\hline \multicolumn{2}{|c|}{ Providers Domain } & Product Domain & Customers Domain & \\
\hline $\begin{array}{l}\text { Key Partners } \\
\text { With whom and how to cooperate in } \\
\text { providing a solution that enhances the } \\
\text { lifetime of product, parts, and components? } \\
\text { P23 (b1)-Provide instruction and training } \\
\text { for providers' workforce for services that } \\
\text { enhance product lifetime } \\
\text { P31 (b3)-Define maintenance system } \\
\text { structure-centralized, decentralised, } \\
\text { or distributed } \\
\text { P32 (b3)-Identify and develop partners } \\
\text { for maintenance provision } \\
\text { P33 (b3)-Establish a close relationship } \\
\text { between the service provider and } \\
\text { manufacturer to facilitate obtaining } \\
\text { knowledge for maintenance } \\
\text { P40 (b5)-Identify and develop partners } \\
\text { for product collection } \\
\text { P41 (b5)-Identify and develop partners } \\
\text { for the second life of products-e.g., repair } \\
\text { shop, second-hand store, charity } \\
\text { P47 (b6)-Establish a close relationship } \\
\text { between the service provider and } \\
\text { manufacturer to facilitate obtaining } \\
\text { knowledge for reprocessing }\end{array}$ & $\begin{array}{l}\text { Key Activities } \\
\text { What do we need to do to } \\
\text { produce, market, and distribute } \\
\text { a solution that enhances the } \\
\text { lifetime of product, parts, } \\
\text { and components? } \\
\text { P29 (b2)-Identify and adjust } \\
\text { spare parts replacement to part } \\
\text { and product lifecycles } \\
\text { separately } \\
\text { P42 (b5)-Elaborate } \\
\text { reverse-logistic schemes } \\
\text { building upon } \\
\text { forward-logistics capabilities } \\
\text { Key Resources } \\
\text { What are the main assets we } \\
\text { need to have to produce, market, } \\
\text { and distribute a solution that } \\
\text { enhances the lifetime of product, } \\
\text { parts, and components? } \\
\text { P31 (b3)-[see Key Partners] }\end{array}$ & $\begin{array}{l}\text { Product Features } \\
\text { What do we need to change in the } \\
\text { physical product to enable a solution } \\
\text { that enhances the lifetime of product, } \\
\text { parts, and components? } \\
\text { P34 (b3)-Enable remote monitoring of } \\
\text { product condition to predict failure } \\
\text { P35 (b3)—Enable remote maintenance } \\
\text { of products through virtual reality } \\
\text { P36 (b3)-Provide repair kits } \\
\text { for consumers } \\
\text { P38 (b4)-Enable upgrading by } \\
\text { designing easy-to-upgrade products } \\
\text { P43 (b5)-Redesign packaging to } \\
\text { facilitate product retrieval } \\
\text { P48 (b6)-Enable remanufacturing by } \\
\text { designing easy-to-remanufacture } \\
\text { products } \\
\text { P50 (b7)-Use extended-lifetime } \\
\text { materials that require less maintenance } \\
\text { than their counterparts } \\
\text { P51 (b7)-Design robust products for } \\
\text { longer lifetimes } \\
\text { P52 (b7)-Redesign packaging for } \\
\text { optimal lifespan considering multiple } \\
\text { uses of transported products }\end{array}$ & $\begin{array}{l}\text { Customer Relationships } \\
\text { How should we communicate and connect to our } \\
\text { market to enable a solution that enhances the lifetime } \\
\text { of product, parts, and components? } \\
\text { P24 (b1)—Provide knowledge to consumers to keep } \\
\text { products in good condition } \\
\text { P25 (b1)—Raise awareness of consumers for } \\
\text { behaviours that enhance product lifetime } \\
\text { P26 (b1)—Share maintenance guidelines and reliable } \\
\text { service providers with clients } \\
\text { P27 (b1)—Elaborate and disseminate instructions to } \\
\text { prevent improper use of products by clients } \\
\text { P36 (b3)—-[see Product Features] } \\
\text { P37 (b3)—Elaborate clear rules and contracts for } \\
\text { maintenance-e.g., define product and part } \\
\text { conditions, frequencies, and responsibilities } \\
\text { P39(b4)- Elaborate clear rules and contracts for } \\
\text { product upgrading—e.g., define product and part } \\
\text { conditions, frequencies, and responsibilities } \\
\text { P44 (b5)-Accept products of different } \\
\text { manufacturers-e.g., multiple brands } \\
\text { P45 (b5)-Encourage consumers to bring their own } \\
\text { packaging/container for consumable products } \\
\text { P49 (b6)-Elaborate clear rules for reconditioning, } \\
\text { refurbishing, or remanufacturing-e.g., define product } \\
\text { and part conditions and responsibilities }\end{array}$ & $\begin{array}{l}\text { Channels } \\
\text { How should we reach and } \\
\text { deliver our solution to our } \\
\text { market to enhance the lifetime } \\
\text { of product, parts, } \\
\text { and components? } \\
\text { P28 (b1)—-Develop a web-based } \\
\text { platform to facilitate access } \\
\text { to instructions } \\
\text { P30 (b2)-Facilitate selection } \\
\text { and acquisition of spare parts } \\
\text { P46 (b5)-Enable retrieving } \\
\text { products after } \\
\text { customer-provider contract is } \\
\text { over for new customer use }\end{array}$ \\
\hline
\end{tabular}


Two identified practices facilitate Upgrading (b4) specific parts while maintaining functional products' subsystems or components. Designing easy-to-upgrade products is a practice in the product domain. Sousa-Zomer and Cauchick Miguel [36] describe a drinking water system as equipment designed for upgrading, minimizing material consumption, waste generation, and the need for new products. Regarding customer relationships, the conditions or frequencies for upgrading need clarification. Xing et al. [31] present one scenario in which specific subsystems of a heating system are upgraded every three years. The authors claim that the energy usage reduction of more efficient systems balances the environmental burden of producing new components to upgrade the product.

The Take-back (b5) strategy heavily relies on reverse logistics to enable an additional lifetime of products. It is enabled by seven practices. Partners for product collection and distribution for second-life products are critical. Revital—an ecologically oriented work integration social enterprise (ECOWISE) - partnered with community waste centers to obtain re-usable items ([33]—Case 1). When collecting products, accepting products from different manufacturers can shape customer relationships. Certain clothes brands accept garments from other brands ([34]—Cases 3, 4, and 5). To distribute collected garments, the same clothes brands partnered with second-hand stores and charity organizations ([34]-Cases 3, 4, and 5). Additionally, a key activity to collect products is to develop reverse-logistic capabilities based upon forward-logistics. In the case of paper mills, a system to facilitate the returning of functional plugs was developed to allow the reuse of components, yielding increased financial and environmental gains [29]. Finally, packaging is also a core feature of the take-back strategy. Household appliances needed packaging redesign to facilitate operator checking, cleaning, and sealing [35], and customers of the community drinking system were encouraged to bring empty containers because there was no packaging available for water refilling [36]. When individual customers are involved in the take-back system, these become essential actors, responsible for taking part in reverse-logistics activities.

The Reprocessing strategy (b6) includes reconditioning, refurbishing, and remanufacturing. It has been facilitated by three practices. Sharing knowledge between the service provider and the manufacturer for reprocessing is described in the soil compactor case ([29]—Case 3), in which information from product use and malfunctioning flows back to improve reprocessing services and costs. In the product domain, such information is also useful to design products that are easy to remanufacture. In the customer domain, clear rules for refurbishing help to communicate the conditions for reprocessing and organizing operations. The haemodialysis equipment provision PSS case describes two types of refurbishment-full refurbishment corresponds to $80 \%$ of the effort of producing a new product, whereas light refurbishment corresponds to $50 \%$ of the production's effort when compared to a new product and applies to products whose internal and external parts are in satisfactory conditions [42].

Designing products or components with Optimal lifespan (b7) is enabled by three practices in the product domain. Designing longer-lifetime products is described in two cases. Amaya et al. [47] show that the design of more robust bikes for sharing by selecting appropriate critical components and materials tripled the lifetime in comparison to standard bikes. In the core plug provision case ([29]—Case 1), the manufacturer designed the product for the longest possible lifespan, and as a result, the product was used in at least five cycles of use, thereby enhancing economic gains. The use of extended-lifetime materials can also be employed to decrease maintenance needs. This practice is described in the Swepac case ([29]—Case 3), where soil compactor painting was replaced by galvanized steel. The authors report that the leasability of soil compactors, i.e., the acceptability for renting, has been preserved for a longer period. Finally, a design for optimal lifespan should also be applied to packaging. In the household equipment renting case, the product packaging was designed to guarantee a higher number of cycles of use than disposable cardboard packages [35]. In all cases of optimal lifespan, production costs are potentially counterbalanced by repeated revenue. 


\subsection{Practices for the Operationalization of Circular Strategies through Cascade Use}

To enhance resource-effectiveness through cascade use, the application of discarded materials and energy needs to be aligned to the business logic. Table 6 presents the practices for three out of four circular strategies that enable cascade use. No practice was identified for 1 1-Industrial Symbiosis, as it was not recognized in any case. In total, 11 practices were identified. Most practices are related to key activities and key partners to enable c2-Facilitate disposal, c3-Recycling, and c4-Energy from waste.

The Facilitate disposal (c2) strategy is enabled by five identified practices. The identify and develop partners for material collection, is a practice described in a few cases. For instance, the re-use enterprise BAN partnered with the municipality of Graz to be an official collection point in the city ([33] - Case 2). One of the interactions to enable the waste-to-energy systems by Usitall AB is the waste-as-material market that enables access to input needed ([51]—Case 1). Another key activity that influences the customer relationship is enabling clients to retrieve used products for recycling when the customer-provider contract is over. In the water purifier provision case, old models are collected for disassembly and recycling when products are replaced by new ones [39]. After collection, processes for sorting specific materials may be developed. For instance, Swedish Biogas International sorts digestible and non-digestible components from animal slaughterhouses for biogas production ([51]—Case 2). Regarding the customer domain, accepting products from different manufacturers also enables facilitated disposal. Two clothing brands accept worn-out clothes from multiple brands for further recycling ([34] —Cases 1 and 2). Finally, creating incentives for customers to obtain specific needed materials is an identified practice. Heidenspass offers bonuses to encourage consumers to deliver specific input materials necessary to manufacture trash-design clothes ([33]-Case 3). In sum, when companies require discarded products as input to their processes, it is crucial that they obtain these materials through active collection and transportation.

For Recycling (c3), three practices were identified. This strategy comprises the following processes-upcycling, downcycling, and biodegradation, which all rely on discarded material as input. One key activity that may enable partnerships is to understand the regional legal framework and incentives to operate recycling. According to Kanda et al. ([51]—Case 3), VafabMiljo engages with funding agencies to explore waste-management markets prior to expanding. In the case described by Sousa-Zomer et al. [39], a subsidiary end-of-life management center is the destination of old water purifiers collected for disassembly and recycling. The Indiska, Boomerang, and Nudie Jeans brands provide collected worn-out clothes as input for decorating products, such as rugs or furniture filling ([34]—Cases 5, 6, and 7). Finally, chemical and biological technology and infrastructure are key resources to enable recycling or biodegradation. The Polyplank ${ }^{\circledR}$ material composed of plastic waste and wood fibres is a proprietary technology of Polyplank AB used to produce the plugs for paper mills ([29]-Case 1). VafabMiljo is specialized in the anaerobic digestion of organic waste and solid waste recycling ([51]—Case 3$)$.

Three practices were identified to facilitate obtaining heat, electricity, or fuel from discarded material, i.e., the Energy from waste (c4) strategy. Understanding the regional legal framework and incentives is also crucial to enable electricity and district heating through the incineration of waste (Usitall AB) ([51]—Case 1) and production of biogas as vehicle fuel from organic material (Swedish Biogas International and Svensk Biogas) ([51]—Cases 2 and 4). In all three cases, this practice is performed prior to setting up waste-to-energy infrastructure. Regarding intangible resources for energy from waste, Svensk Biogas reportedly developed processes for optimizing biogas production to be applied in its own units or through licensing patents to other companies ([51]—Case 4). 
Table 6. Practices for operationalization of circular strategies through cascade use positioned according to the considered BM dimensions.

\begin{tabular}{|c|c|c|c|c|}
\hline \multicolumn{2}{|c|}{ Providers Domain } & \multirow{2}{*}{\begin{tabular}{l}
\multicolumn{1}{c}{ Product Domain } \\
Product Features \\
What do we need to change in \\
the physical product to enable \\
a solution that recovers \\
discarded materials and energy?
\end{tabular}} & \multicolumn{2}{|c|}{ Customers Domain } \\
\hline $\begin{array}{l}\text { Key Partners } \\
\text { With whom and how to } \\
\text { cooperate in providing } \\
\text { a solution that recovers } \\
\text { discarded materials and energy? }\end{array}$ & $\begin{array}{l}\text { Key Activities } \\
\text { What do we need to do to produce, } \\
\text { market, and distribute a solution } \\
\text { that recovers discarded materials } \\
\text { and energy? }\end{array}$ & & $\begin{array}{l}\text { Customer Relationships } \\
\text { How should we communicate } \\
\text { and connect to our market to } \\
\text { enable a solution that recovers } \\
\text { discarded materials and energy? }\end{array}$ & $\begin{array}{l}\text { Channels } \\
\text { How should we reach and } \\
\text { deliver our solution to our } \\
\text { market to recover discarded } \\
\text { materials and energy? }\end{array}$ \\
\hline $\begin{array}{l}\text { P53 (c2)-Identify and develop } \\
\text { partners for material collection } \\
\text { P58 (c3)-Identify and } \\
\text { understand local legal } \\
\text { framework, incentives, } \\
\text { and waste streams to set up } \\
\text { recycling operations } \\
\text { P59 (c3)-Identify and develop } \\
\text { partners for material recycling, } \\
\text { e.g., waste managers or } \\
\text { organisations that use specific } \\
\text { collected streams as input } \\
\text { P61 (c4)-Identify and } \\
\text { understand local legal } \\
\text { framework, incentives, partners } \\
\text { and waste streams to set up } \\
\text { energy from waste operations }\end{array}$ & $\begin{array}{l}\text { P54 (c2)_Enable retrieving } \\
\text { products after customer-provider } \\
\text { contract is over for recycling } \\
\text { P55 (c2)—Develop processes to } \\
\text { enable sorting specific material } \\
\text { from the collected stream } \\
\text { P58 (c3)—-[see Key Partners] } \\
\text { P60 (c3)—Develop chemical and } \\
\text { biological recycling processes } \\
\text { and structure } \\
\text { P61 (c4)—-[see Key Partners] } \\
\text { Key Resources } \\
\text { What are the main assets we need to } \\
\text { have to produce, market, and } \\
\text { distribute a solution that recovers } \\
\text { discarded materials and energy? } \\
\text { P60 (c3)-[see Key Activities] } \\
\text { P62 (c4)—Develop chemical and } \\
\text { biological technology to transform } \\
\text { discarded material into heat, energy, } \\
\text { or fuel source } \\
\text { P63 (c4)—Set up waste to } \\
\text { energy infrastructure }\end{array}$ & - & $\begin{array}{l}\text { P54 (c2)-[see Key Activities] } \\
\text { P56 (c2)-Accept products of } \\
\text { different manufacturers-e.g., } \\
\text { multiple brands } \\
\text { P57 (c2) - Create incentives for } \\
\text { clients or customers to obtain } \\
\text { specific material }\end{array}$ & - \\
\hline
\end{tabular}




\subsection{Practices for Operationalisation of Circular Strategies through Pure Inputs}

To enhance resource-effectiveness through pure inputs, the improved application of materials and energy needs to be aligned to the business logic. Table 7 presents the practices for the five circular strategies that enable pure inputs. In total, 14 practices were identified. Adaptations in product features and key activities are essential to enable $\mathrm{d} 1$ - Renewable sources, $\mathrm{d} 2$ - Fewer resources, $\mathrm{d} 3$ - Bio-based resources, b4-Recyclable resources, and d5-Dematerialization.

The Renewable energy (d1) strategy is enabled by two practices. The application of such a strategy implied infrastructure and product adaptations to enable the use of renewable energy. Specific infrastructure needs to be implemented to keep product fleets charged when transitioning to renewables, as in the case of the rental boat example, in which subsidies were deployed to convert diesel engines into electric ones, as well to set up a grid for charging [43]. In the product domain, systems need to be designed to capture, generate, and function on renewables. Azimut Monitoring redesigned sensors for monitoring urban services to run on solar energy, and thus the solar panel is one of its subsystems [30]. Additionally, the energy heating system described by Xing et al. [31] works on solar energy and natural gas through a collector unit and an auxiliary gas heater.

Two strategies enable Fewer resources (d2) for product and component manufacturing. In the providers' domain, low-impact manufacturing processes enable using fewer resources. In the clothes industry, the reduced use of water, energy, or chemicals is applied to produce clothes by H\&M ([34]-Case 1). An improved ensilage process is reported in the heifer breeding cooperative solution, in which less plastic is employed ([26]—Case 3). In the product domain, designing less powerful products also enables the use of fewer resources. For instance, the utilization of lighter batteries for powering the sensor used to monitor urban services enabled the application of lighter body materials [30]. Moreover, the two-seater Car2go is approximately half the weight of an average car and two-thirds of its size in Germany [45], which enables significant energy gains during the use phase and reduced space requirements for driving and parking.

d3 - Bio-based resources, i.e., the effective use of input materials according to biological cycles, is enabled by three practices. Designing products to be manufactured using only bio-based materials was identified in the clothing industry-Jeans made of $100 \%$ organic and fair-trade cotton ([34] —Cases 4 and 7) and in the waste management industry, Swedish Biogas International and Svensk Biogas make use of organic waste as input for fuel ([51] - Cases 2 and 4). Implementing material and product certification systems internally or with external partners is a widespread practice in the clothing industry. H\&M follows a classification system developed by a not-for-profit organization, whereas Gina Tricot and Filippa K implemented their own systems ([34]—Cases 1, 4 and 8). Finally, bio-based materials are employed in consumables to be used during other products' lifetime and to shape the customer relationship. Lindex, for instance, sells organic cleaning products for washing clothes ([34]-Case 3). Additionally, the low-conductivity characteristic of purified water employed to clean building exteriors suppresses the use of detergent and accelerates the processes of cleaning and drying ([29]—Case 2).

In the technical cycles, the Recyclable resources (d4) strategy is enabled by four identified practices. Designing products to be manufactured using recyclable inputs was identified in the clothing industry, including fully recyclable clothes by Filippa K, and recyclable fibers to be introduced in clothes production by H\&M, Gina Tricot, and UFTD ([34]—Cases 1, 4, 8, and 9). Additionally, paper mill plugs are made of plastic waste and wood fiber composite material in the Polyplank case ([29]—Case 2). When designing products to use recyclable resources, the concept of upcycling should be considered from the start. Upcycling is practiced by the trash design company, Heidenspass, which conceptualizes high-end design products that enable creating value from discarded material ([33]—Case 3). 
Table 7. Practices for operationalization of circular strategies through pure inputs positioned according to the considered BM dimensions.

\begin{tabular}{|c|c|c|c|c|}
\hline \multicolumn{2}{|c|}{ Providers Domain } & \multirow[b]{2}{*}{$\begin{array}{l}\text { Product Domain } \\
\text { Product Features } \\
\text { What do we need to change in the physical } \\
\text { product to enable a solution that enhances } \\
\text { the application of materials and energy? } \\
\text { P65 (d1)-Design/utilise products and } \\
\text { components that capture, generate, } \\
\text { and function on renewable energy } \\
\text { P67 (d2)-Design lighter, smaller, and less } \\
\text { powerful products } \\
\text { P69 (d3)-Provide bio-based consumables } \\
\text { to maintain other products' lifetimes } \\
\text { P70 (d3)-Design products, components, } \\
\text { or consumables applying bio-based } \\
\text { material only-organic or } \\
\text { biodegradable inputs } \\
\text { P72 (d4)-Design products, components or } \\
\text { consumables applying recycled materials } \\
\text { P73 (d4)-Design products for } \\
\text { material recovery } \\
\text { P74 (d4)-Design for upcycling, } \\
\text { e.g., the 'trash design' approach for } \\
\text { high-end products } \\
\text { P75 (d5)-Substitute or eliminate the need } \\
\text { for products or functions } \\
\text { P76 (d5)-Design for non-optimal product } \\
\text { functionality but for system functionality }\end{array}$} & \multicolumn{2}{|c|}{ Customers Domain } \\
\hline $\begin{array}{l}\text { Key Partners } \\
\text { With whom and how to cooperate } \\
\text { in providing a solution that } \\
\text { enhances the application of } \\
\text { materials and energy? } \\
\text { P68 (d3)-Develop and } \\
\text { implement material and product } \\
\text { certification systems (with or } \\
\text { without an external partner) } \\
\text { P71 (d4)-Develop and } \\
\text { implement material and product } \\
\text { certification systems (with or } \\
\text { without an external partner) }\end{array}$ & $\begin{array}{l}\text { Key Activities } \\
\text { What do we need to do to } \\
\text { produce, market, and distribute } \\
\text { a solution that enhances the } \\
\text { application of materials } \\
\text { and energy? } \\
\text { P66 (d2)-Develop low-impact } \\
\text { manufacturing processes that } \\
\text { use less water, energy, } \\
\text { or toxic material } \\
\text { P68 (d3)—-[see Key Partners] } \\
\text { P71 (d4)—-[see Key Partners] } \\
\text { Key Resources } \\
\text { What are the main assets we } \\
\text { need to have to produce, market, } \\
\text { and distribute a solution that } \\
\text { enhances the application of } \\
\text { materials and energy? } \\
\text { P64 (d1)-Develop } \\
\text { infrastructure to charge fleet } \\
\text { using renewable energy }\end{array}$ & & $\begin{array}{l}\text { Customer Relationships } \\
\text { How should we communicate and } \\
\text { connect to our market to enable } \\
\text { a solution that enhances the } \\
\text { application of materials and energy? } \\
\text { P69 (d3)_[see Product Features] }\end{array}$ & $\begin{array}{l}\text { Channels } \\
\text { How should we reach and } \\
\text { deliver our solution to our } \\
\text { market to enhance the } \\
\text { application of materials } \\
\text { and energy? } \\
\text { P77 (d5)_Favour the use of } \\
\text { online platforms and virtual } \\
\text { reality to enable access to } \\
\text { services and interaction } \\
\text { among clients }\end{array}$ \\
\hline
\end{tabular}


In the last inner circles strategy, three practices were identified to enable Dematerialization (d5). Within the product domain, dematerialization can be achieved by substituting or eliminating the need for products or functions. For example, the community water system substitutes bottled water selling [36]. Designing for non-optimal product functionality was another recognized practice to achieve dematerialization. Salazar et al. [30] use the term degradation to describe the purposeful non-optimization of individual functions of products or services without compromising user satisfaction and potentially reducing environmental impacts. In the monitoring solution for urban services, function-oriented indicators were prioritized over increased data acquisition, enabling the use of more basic sensors, which need less energy to function [30]. In the end, the general function of urban services monitoring was even expanded because decision-making was enhanced through the use of indicators.

Finally, dematerialization can be enabled by favoring the use of online platforms and virtual reality for accessing services and enabling interaction among clients. For instance, an internet information system substitutes booklets and kiosks to provide tourist information in the boat rental case [43]. Augmented reality is applied to virtually deliver product maintenance and (dis)assembly guidance [40], which disruptively substitutes the use of manuals for such activities. Additionally, sharing platforms commonly rely on online platforms to assist in the selection of equipment and provision of information for practical use [35], location and booking of bikes and cars [44-47], and even getting access to cars' actual conditions of use [44]. A free-floating system for sharing vehicles makes fixed stations unnecessary and enables one-way usage [45]. Thus, virtualizing the access to products and services is a recurrent practice to enable dematerialization and can work as a source for usage information.

The identification of practices empirically demonstrates specific manners to operationalize strategies in the examined cases. Nevertheless, although the combined application of strategies is evident through the practical perspective analysis, there is room for clarification. The fact that, in all cases, at least two strategies were applied in combination, and evidence of the combined application of strategies, such as the use of facilitated disposal (c2) to promote the use of recyclable resources (d4), indicate further scope to investigate relationships among strategies. The likely dependency among strategies towards enhanced circularity justifies the occurrence and co-occurrence analyses in the next section.

\section{Circular Strategy Occurrence and Co-Occurrence in Sustainability-Oriented PSS Cases}

The results of the cross-cases occurrence analysis reveal classes of strategies and strategy frequency with respect to the set of considered cases-see Table 8 . The results are segmented according to the three types of PSS. From all 45 cases, 17 cases are product-oriented (PO), 21 are use-oriented (UO), and 7 are result-oriented (RO). Although PO PSS cases rely mainly on circling longer strategies as additional services offered along with ownership-based transactions, all UO and RO PSS cases rely on at least one inner circle strategy. Overall, most cases (78\%) make use of at least one inner circle strategy. On the contrary, cascade use strategies are less occurrent $(40 \%)$. Certain strategies show higher occurrence: 24 cases (53\%) provide or facilitate failure prediction, maintenance, and/or repair services-b3, which allow products and components to circle longer; 18 cases (40\%) sell access to products for a specific period-a4; and 18 cases (40\%) provide knowledge-based services for the effective use of products-a5.

Some specific insights are derived from the strategies' occurrence. First, UO PSS cases are those that most apply strategies to enhance the lifetime of products $(76 \%$ of cases apply circling longer strategies). This pattern reinforces that if products are designed, manufactured, and maintained for longer, the revenues from renting or leasing for longer or for more use cycles are more significant. Although PO PSS still relies on the transaction of products, the high occurrence of facilitating disposal services (59\% of cases) indicate that product ownership is a real issue for clients in this type of transaction when a product reaches the end of its lifetime. Moreover, a robust application of pure input strategies in the considered set of cases (51\% of cases) indicates that companies seek to enhance the application of materials and energy when implementing sustainability-oriented PSS cases. Finally, 
although reduced consumption (a1) and upgrading (b4) are promising strategies to achieve a CE, these are still rarely applied or discussed according to the analysis.

Table 8. Occurrence of circular strategies in considered PSS cases according to PSS type.

\begin{tabular}{lcccc}
\hline \multirow{2}{*}{$\begin{array}{l}\text { Circular Strategies } \\
\text { (Strategic and Conceptual Levels) }\end{array}$} & \multicolumn{3}{c}{ Occurrence in Considered PSS Cases } \\
\cline { 2 - 5 } & PO PSS & UO PSS & RO PSS & All PSS \\
& $\mathbf{1 7}$ Cases & 21 Cases & 7 Cases & 45 Cases \\
\hline a1-Reduced consumption & $0 \%$ & $14 \%$ & $0 \%$ & $7 \%$ \\
a2-Sharing products & $0 \%$ & $38 \%$ & $14 \%$ & $20 \%$ \\
a3-Result provision & $6 \%$ & $5 \%$ & $86 \%$ & $18 \%$ \\
a4-Access provision & $0 \%$ & $81 \%$ & $14 \%$ & $40 \%$ \\
a5-Effective use instruction & $41 \%$ & $38 \%$ & $43 \%$ & $40 \%$ \\
A-Inner Circles & $41 \%$ & $100 \%$ & $100 \%$ & $78 \%$ \\
\hline b1-Extended use instruction & $18 \%$ & $24 \%$ & $14 \%$ & $20 \%$ \\
b2-Spare parts & $6 \%$ & $14 \%$ & $14 \%$ & $11 \%$ \\
b3-Maintenance & $41 \%$ & $62 \%$ & $57 \%$ & $53 \%$ \\
b4-Upgrading & $6 \%$ & $5 \%$ & $14 \%$ & $14 \%$ \\
b5-Take-back & $41 \%$ & $29 \%$ & $29 \%$ & $33 \%$ \\
b6-Reprocessing & $18 \%$ & $19 \%$ & $14 \%$ & $18 \%$ \\
b7-Optimal lifespan & $0 \%$ & $14 \%$ & $29 \%$ & $11 \%$ \\
B-Circling Longer & $65 \%$ & $76 \%$ & $57 \%$ & $69 \%$ \\
\hline c1-Industrial Symbiosis & $0 \%$ & $0 \%$ & $0 \%$ & $0 \%$ \\
c2-Facilitate disposal & $59 \%$ & $10 \%$ & $43 \%$ & $33 \%$ \\
c3-Recycling & $41 \%$ & $19 \%$ & $43 \%$ & $33 \%$ \\
c4-Energy from waste & $12 \%$ & $0 \%$ & $14 \%$ & $7 \%$ \\
C-Cascade Use & $59 \%$ & $19 \%$ & $57 \%$ & $40 \%$ \\
\hline d1-Renewable sources & $0 \%$ & $19 \%$ & $0 \%$ & $9 \%$ \\
d2-Fewer resources & $6 \%$ & $14 \%$ & $0 \%$ & $9 \%$ \\
d3-Bio-based resources & $35 \%$ & $5 \%$ & $29 \%$ & $20 \%$ \\
d4-Recyclable resources & $18 \%$ & $10 \%$ & $14 \%$ & $22 \%$ \\
d5-Dematerialisation & $6 \%$ & $38 \%$ & $14 \%$ & $22 \%$ \\
D-Pure Inputs & $47 \%$ & $52 \%$ & $57 \%$ & $51 \%$ \\
\hline & & & & \\
\hline
\end{tabular}

The co-occurrences of strategies and classes thereof are depicted in Tables 9 and 10 following the application of the Jaccard index. The Jaccard value varies from 0 to 1 , where a value closer to 1 represents a higher frequency with which two strategies are concomitantly applied in the same case. This implies that pairs of strategies may be interdependent or complementary in a sustainable PSS solution. For example, of every time a5-Effective use instruction or b1-Extended use instruction was applied (union set of 21), in $29 \%$ of the times, both strategies were applied in combination (intersection set of 6). Therefore, the co-occurrence of $(a 5, b 1)$ is given by $J_{(a 5, b 1)}=0.29$ or $29 \%$ on a scale of 0 to $100 \%$. The same logic applies to the aggregate analysis.

As Table 9 shows, specific strategies of the same class and different classes of strategies are applied together. A considerable number of cases combine access provision (a4) and maintenance (b3) strategies (40\% co-occurrence among both strategies). This reinforces that providers seek to keep products functioning for as long as possible when they retain ownership of products. Robust maintenance services can enhance the level of use of products, especially if failure is predictable. Knowledge-based services to increase the level of use (a5) and lifetime (b1) are also commonly combined (29\% co-occurrence). This indicates that whenever setting trust-based relationships between providers, and among providers and clients, consultancy and knowledge sharing become more attractive while decreasing the dependency on ownership-based transactions. Furthermore, sharing products (a2) is highly connected to dematerialization (d5), because online platforms are powerful enablers of product sharing. 
Table 9. Strategy co-occurrence in sustainable PSS sample of cases. Only circular strategy codes are represented to improve readability.

\begin{tabular}{|c|c|c|c|c|c|c|c|c|c|c|c|c|c|c|c|c|c|c|c|c|c|}
\hline St./St. & a1 & a2 & a3 & a4 & a5 & b1 & b2 & b3 & b4 & b5 & b6 & b7 & c1 & c2 & c3 & c4 & d1 & d2 & d3 & d4 & d5 \\
\hline \multirow[t]{21}{*}{ a1 } & 1.00 & 0.09 & & 0.17 & 0.05 & & 0.14 & 0.04 & & 0.06 & 0.10 & & & 0.06 & 0.06 & & 0.17 & & 0.09 & 0.13 & 0.08 \\
\hline & a2 & 1.00 & 0.06 & 0.23 & 0.17 & 0.13 & & 0.18 & 0.09 & 0.14 & 0.13 & 0.27 & & & 0.10 & & 0.08 & 0.18 & & & 0.58 \\
\hline & & a3 & 1.00 & & 0.18 & 0.13 & 0.08 & 0.19 & 0.10 & 0.05 & 0.07 & 0.08 & & 0.10 & 0.16 & 0.10 & & & 0.13 & & 0.06 \\
\hline & & & a4 & 1.00 & 0.16 & 0.13 & 0.21 & 0.40 & 0.05 & 0.27 & 0.18 & 0.21 & & 0.10 & 0.14 & & 0.22 & 0.10 & 0.04 & 0.14 & 0.27 \\
\hline & & & & a5 & 1.00 & 0.29 & 0.15 & 0.24 & & 0.10 & 0.08 & 0.05 & & 0.27 & 0.23 & 0.11 & 0.10 & 0.16 & 0.23 & 0.04 & 0.22 \\
\hline & & & & & b1 & 1.00 & 0.27 & 0.32 & & 0.09 & 0.21 & 0.08 & & 0.04 & & & & 0.08 & & & 0.06 \\
\hline & & & & & & b2 & 1.00 & 0.21 & & 0.11 & 0.18 & 0.11 & & 0.11 & 0.12 & & & & & 0.10 & \\
\hline & & & & & & & b3 & 1.00 & 0.13 & 0.30 & 0.33 & 0.21 & & 0.18 & 0.27 & & 0.04 & 0.04 & 0.03 & 0.03 & 0.17 \\
\hline & & & & & & & & $\mathbf{b 4}$ & 1.00 & 0.13 & 0.22 & 0.14 & & & 0.06 & & 0.17 & & & & 0.08 \\
\hline & & & & & & & & & b5 & 1.00 & 0.28 & 0.25 & & 0.20 & 0.26 & & 0.06 & & 0.20 & 0.24 & 0.14 \\
\hline & & & & & & & & & & b6 & 1.00 & 0.30 & & 0.10 & 0.16 & & & & & & 0.13 \\
\hline & & & & & & & & & & & b7 & 1.00 & & 0.05 & 0.19 & & & & & 0.10 & 0.25 \\
\hline & & & & & & & & & & & & c1 & 0.00 & & & & & & & & \\
\hline & & & & & & & & & & & & & c2 & 1.00 & 0.61 & 0.20 & & 0.06 & 0.26 & 0.17 & \\
\hline & & & & & & & & & & & & & & c3 & 1.00 & & & 0.06 & 0.15 & 0.18 & 0.09 \\
\hline & & & & & & & & & & & & & & & c4 & 1.00 & & & 0.20 & & \\
\hline & & & & & & & & & & & & & & & & d1 & 1.00 & 0.14 & & & 0.27 \\
\hline & & & & & & & & & & & & & & & & & d2 & 1.00 & 0.08 & 0.11 & 0.27 \\
\hline & & & & & & & & & & & & & & & & & & d3 & 1.00 & 0.25 & \\
\hline & & & & & & & & & & & & & & & & & & & d4 & 1.00 & \\
\hline & & & & & & & & & & & & & & & & & & & & d5 & 1.00 \\
\hline
\end{tabular}

$\begin{array}{lllll}0 & 0.2 & 0.4 & 0.6 & 0.8\end{array}$

Note:

, Tables 9 and 10 follows number and color logics to facilitate visualization of synergies among strategies and classes of strategies. 
Table 10. Strategy aggregate co-occurrence in sustainable PSS sample of cases.

\begin{tabular}{ccccc}
\hline Type/Type & A & B & C & D \\
\hline A-Inner Circles & 1.00 & 0.57 & 0.33 & 0.49 \\
\cline { 2 - 5 } B-Circling Longer & 1.00 & 0.29 & 0.32 \\
\hline & C-Cascade Use & 1.00 & 0.28 \\
& & D-Pure Inputs & 1.00 \\
\hline
\end{tabular}

Tables 9 and 10 follows number and color logics to facilitate visualization of synergies among strategies and classes of strategies.

Regarding the end-of-life strategies, Take-back (b5) and facilitate disposal (c2) are typical enabling strategies that make use of reverse logistics to transport defective products for the application of further circling longer strategies or collapsed products to recover material and energy from them. Take-back systems (b5) enable maintenance (b3) in 30\% of the identified cases and reprocessing (b6) services in $28 \%$ of them. Maintenance and reprocessing services are commonly combined (33\% of co-occurrence), indicating that a process to systematically maintain defective products and only reprocess them when the product integrity is too low for maintenance can lead to optimal resource-effectiveness. A collection system is also essential to creating value from collapsed products and components through recycling (c3) (61\% co-occurrence to facilitate disposal (c2)) and energy from waste solutions (c4) (20\% co-occurrence to facilitate disposal (c2)). When companies face disposable materials as a critical input for their processes, it is crucial to obtain them through collection and transportation, because forward logistics are more mature than closed-loop logistics.

The co-occurrence analysis demonstrates that combinations of strategies were not observed in the available set of cases. This indicates a lack of connection among these strategies. For instance, in the sample of cases, upgrading (b4) is still quite disconnected from all the inner circle strategies, indicating opportunities for PSS solutions that offer clients access to new versions of the solution without abdicating the already installed product. Eco-efficiency gains may improve if PSS is thought of beyond a single customer or the lifetime of a single version of a product. A lack of connection is also apparent among the optimal lifespan (b7), cascade use, and pure input strategies, indicating that when a product is designed for an advanced lifetime, less effort is made to enhance the recovery or use of materials and energy.

Table 10 shows that, in the aggregate, in the conceptual perspective of the circular innovation framework, strategies which increase the life of products and components (B-Circling Longer) and that thoroughly consider materials and energy as inputs (D-Pure Inputs) are consistently combined with inner circle (A) strategies in sustainable PSS cases- $\mathrm{J}_{(\mathrm{A}, \mathrm{B})}=57 \%$ and $\mathrm{J}_{(\mathrm{B}, \mathrm{D})}=49 \%$. This indicates that strategies from the inner circles, which are core aspects of UO and RO PSS, have substantial synergy with the other classes of strategies. Inner circle strategies are, thus, powerful enablers of different levels of resource-effectiveness. Finally, the low occurrence and co-occurrence of cascade use strategies $(C)$ with all the other categories of strategies in the sample of cases $\left(J_{(A, C)}=33 \%, J_{(B, C)}=29 \%\right.$, and $\mathrm{J}_{(\mathrm{C}, \mathrm{D})}=28 \%$ ) indicate that material and energy recovery from discarded products are still poorly considered in PSS, and have the potential for positive impact.

\section{Conclusions and Research Limitations}

Aiming to facilitate decision-making in circular BMI, this study constitutes an extensive and systematic review of sustainable PSS cases to assess the application of well-disseminated circular strategies based on resource-effectiveness logic. The findings provide further avenues to connect the $\mathrm{CE}$ and PSS bodies of knowledge towards sustainable impacts. The circular innovation framework proposed in this research connects conceptual to practical decisions for circular innovation, which is applicable in the scope of PSS. This rationale enables progressive detailing of patterns for circular innovation. Strategy occurrence provides a panorama of applications in product, use, and result-oriented solutions. It clarifies the main possibilities among strategic choices to define the value proposition and enable 
enhanced resource-effectiveness. A co-occurrence analysis describes synergies and complementarity among different types of circular strategies, indicating that some are prone to be combined to realize more positive impacts through product-service bundles.

Synergies among combinations of different approaches towards more positive impacts were already discussed by Bocken et al. [65]. In PSSs, a clear perspective of the lifecycle impacts of the solution is essential to combine circular strategies for improved environmental impacts. In cases in which most of the impacts occur in the use phase, circling longer strategies alone may not lead to improved energy use, as already demonstrated by Gutowski et al. [66], where remanufacturing of outdated versions of products led to higher overall negative impacts compared to versions of the product that use less energy during the use phase. This rebound effect of products with a longer life was also indicated by Intlekofer, Bras, and Ferguson [67] where reduced life cycles could be beneficial in products with high impacts during use. Such possibilities for rebound effects reinforce the need to consider whether enhanced resource-effectiveness is delivered, considering the different aggregation levels of resources only enabled by a combination of strategies.

Furthermore, when conceptual and strategic perspectives towards circularity in PSS solutions are aligned, certain options are still open in the practical perspective. The practices for operationalization clarify the BM rationale to enable circular strategies based on cases from the literature. Practices and published cases can help organizations to define more sustainable PSSs by identifying the efforts needed to adjust: The structure from the suppliers' side, the links to customers, and products' characteristics.

This research builds on the increased body of case studies which claim and discuss sustainable impacts in the PSS field to identify patterns of circular strategy adoption and operationalization. The 45 identified cases of sustainability-oriented PSSs cover an adequate number of industries and perspectives, comprising a relevant body of knowledge to investigate circular strategies. However, two limitations arise from the adopted research approach. First, while journal descriptions of cases tend to be highly detailed and reliable, strategy identification depends on the description from secondary sources seeking to clarify a variety of research gaps. Thus, the non-marking of a given strategy does not guarantee that it is not performed in that specific case. Second, frequency analysis tends to be sensitive to small samples and thus should be cautiously considered. Parsimony is required, particularly in situations in which a given strategy was identified in a few cases.

Nevertheless, the combination of systematic literature review and content analysis is also an advantage of this work. It provides the opportunity to continuously develop an understanding of the application of circular strategies in PSS or other fields. New practices and further understanding of the combination of strategies may emerge if a broader extent of cases is considered to investigate the research questions posed in this work, building upon the database created in this study. Other terms such as service-dominant logic, functional product, and sharing economy could be used to expand the scope. Additionally, cases from other bodies of knowledge could be included for other parallel investigations, e.g., to compare the application of circular strategies in different fields related to the CE umbrella.

Author Contributions: D.G. and J.M.H.d.C. were responsible for the conceptualization of the paper. D.G. and A.H.T. were in responsible for the data curation and investigation operationalization. The statistical analysis was performed by M.E. The methodology was designed and written by D.G., J.M.H.d.C. and A.H.T. The original draft was created by D.G. The paper review \& editing was done by all authors.

Funding: This research was funded by the Coordination for the Improvement of Higher Education Personnel (CAPES); and the São Paulo Research Foundation (FAPESP).

Acknowledgments: The authors would like to thank The Coordination for the Improvement of Higher Education Personnel (CAPES); and The São Paulo Research Foundation (FAPESP), for financially supporting this research, under the process 2017/06144-5. The opinions, hypotheses, conclusions and recommendations expressed in this material are the responsibility of the authors and do not necessarily reflect the views of FAPESP and CAPES. We would also like to thank Ing. Henrique Rozenfeld, from São Carlos School of Engineering at the University of São Paulo, for the discussions and suggestions that contributed to the improvement of this article.

Conflicts of Interest: The authors declare no conflict of interest. 


\section{References}

1. Geissdoerfer, M.; Savaget, P.; Bocken, N.M.P.; Hultink, E.J. The Circular Economy-A new sustainability paradigm? J. Clean. Prod. 2017, 143, 757-768. [CrossRef]

2. Ellen MacArthur Foundation. Towards the Circular Economy: Economics and Business Rationale for an Accelerated Transition; MacArthur Foundation: Cowes, UK, 2012; p. 96.

3. Kirchherr, J.; Reike, D.; Hekkert, M. Conceptualizing the circular economy: An analysis of 114 definitions. Resour. Conserv. Recycl. 2017, 127, 221-232. [CrossRef]

4. Bocken, N.M.P.; de Pauw, I.; Bakker, C.A.; van der Grinten, B. Product design and business model strategies for a circular economy. J. Ind. Prod. Eng. 2016, 33, 308-320. [CrossRef]

5. Linder, M.; Williander, M. Circular Business Model Innovation: Inherent Uncertainties. Bus. Strateg. Environ. 2015, 26, 182-196. [CrossRef]

6. Antikainen, M.; Valkokari, K. A Framework for Sustainable Circular Business Model Innovation. Technol. Innov. Manag. Rev. 2016, 6, 5-12. [CrossRef]

7. Osterwalder, A.; Pigneur, Y. Clarifying Business Models: Origins, Present, and Future of the Concept Clarifying Business Models: Origins, Present, and Future of the Concept. Commun. Assoc. Inf. Syst. 2005, $15,1-125$.

8. Richardson, J. The business model: An integrative framework for strategy execution. Strateg. Chang. 2008, 17, 133-144. [CrossRef]

9. Lahti, T.; Wincent, J.; Parida, V. A definition and theoretical review of the circular economy, value creation, and sustainable business models: Where are we now and where should research move in the future? Sustainability 2018, 10, 2799. [CrossRef]

10. Brandstotter, M.; Haberl, M.; Knoth, R.; Kopacek, B.; Kopacek, P. IT on demand-towards an environmental conscious service system for Vienna (AT). In Proceedings of the Third International Symposium on Environmentally Conscious Design and Inverse Manufacturing-EcoDesign, Tokyo, Japan, 8-11 December 2003; pp. 799-802.

11. Baines, T.S.; Lightfoot, H.W.; Evans, S.; Neely, A.; Greenough, R.; Peppard, J.; Roy, R.; Shehab, E.; Braganza, A.; Tiwari, A.; et al. State-of-the-art in product-service systems. Proc. Inst. Mech. Eng. Part B J. Eng. Manuf. 2007, 221, 1543-1552. [CrossRef]

12. Goedkoop, M.J.; Van Halen, C.J.G.; Te Riele, H.R.M.; Rommens, P.J.M. Product Service Systems, Ecological and Economic Basics; Ministry of Environment: The Hague, The Netherlands, 1999.

13. Manzini, E.; Vezzoli, C. A strategic design approach to develop sustainable product service systems: Examples taken from the "environmentally friendly innovation" Italian prize. J. Clean. Prod. 2003, 11, 851-857. [CrossRef]

14. Mont, O.K. Clarifying the concept of product-service system. J. Clean. Prod. 2002, 10, 237-245. [CrossRef]

15. Reim, W.; Parida, V.; Örtqvist, D. Product-Service Systems (PSS) business models and tactics-A systematic literature review. J. Clean. Prod. 2015, 97, 61-75. [CrossRef]

16. Tukker, A.; Tischner, U. Product-services as a research field: Past, present and future. Reflections from a decade of research. J. Clean. Prod. 2006, 14, 1552-1556. [CrossRef]

17. Stahel, W.R. Circular Economy. Nature 2016, 435-438. [CrossRef] [PubMed]

18. Pieroni, M.P.; Blomsma, F.; McAloone, T.C.; Pigosso, D.C.A. Enabling circular strategies with different types of product/service-systems. Procedia CIRP 2018, 73, 179-184. [CrossRef]

19. Gaiardelli, P.; Resta, B.; Martinez, V.; Pinto, R.; Albores, P. A classification model for product-service offerings. J. Clean. Prod. 2014, 66, 507-519. [CrossRef]

20. Tukker, A. Product services for a resource-efficient and circular economy-A review. J. Clean. Prod. 2015, 97, 76-91. [CrossRef]

21. Michelini, G.; Nunes, R.N.; Cunha, R.N.; Costa, J.M.H.; Ometto, A.R. PSS conducting the transition to circular economy. Procedia CIRP 2017, 2-6. [CrossRef]

22. Bocken, N.; Strupeit, L.; Whalen, K.; Nußholz, J. A Review and Evaluation of Circular Business Model Innovation Tools. Sustainability 2019, 11, 2210. [CrossRef]

23. Casadesus-masanell, R.; Ricart, J.E. From Strategy to Business Models and onto Tactics. Long Range Plann. 2010, 43, 195-215. [CrossRef] 
24. Moher, D.; Liberati, A.; Tetzlaff, J.; Altman, D.G.; Altman, D.; Antes, G.; Atkins, D.; Barbour, V.; Barrowman, N.; Berlin, J.A.; et al. Preferred reporting items for systematic reviews and meta-analyses: The PRISMA statement. PLoS Med. 2009, 6, e1000097. [CrossRef] [PubMed]

25. Elo, S.; Kyngäs, H. The qualitative content analysis process. J. Adv. Nurs. 2008, 62, 107-115. [CrossRef] [PubMed]

26. Pereira, Á.; Carballo-Penela, A.; González-López, M.; Vence, X. A case study of servicizing in the farming-livestock sector: Organisational change and potential environmental improvement. J. Clean. Prod. 2016, 124, 84-93. [CrossRef]

27. Song, W.; Sakao, T. An environmentally conscious PSS recommendation method based on users' vague ratings: A rough multi-criteria approach. J. Clean. Prod. 2018, 172, 1592-1606. [CrossRef]

28. Chen, D.; Chu, X.; Yang, X.; Sun, X.; Li, Y.; Su, Y. PSS solution evaluation considering sustainability under hybrid uncertain environments. Expert Syst. Appl. 2015, 42, 5822-5838. [CrossRef]

29. Lindahl, M.A.; Sundin, E.B.; Sakao, T.A. Environmental and economic benefits of Integrated Product Service Offerings quantified with real business cases. J. Clean. Prod. 2014, 64, 288-296. [CrossRef]

30. Salazar, C.; Lelah, A.; Brissaud, D. Eco-designing product service systems by degrading functions while maintaining user satisfaction. J. Clean. Prod. 2015, 87, 452-462. [CrossRef]

31. Xing, K.; Wang, H.F.; Qian, W. A sustainability-oriented multi-dimensional value assessment model for product-service development. Int. J. Prod. Res. 2013, 51, 5908-5933. [CrossRef]

32. Peruzzini, M.; Germani, M. Design for sustainability of product-service systems. Int. J. Agil. Syst. Manag. 2014, 7, 206-219. [CrossRef]

33. Gelbmann, U.; Hammerl, B. Integrative re-use systems as innovative business models for devising sustainable product-service-systems. J. Clean. Prod. 2015, 97, 50-60. [CrossRef]

34. Stål, H.I.; Jansson, J. Sustainable Consumption and Value Propositions: Exploring Product-Service System Practices Among Swedish Fashion Firms. Sustain. Dev. 2017, 25, 546-558. [CrossRef]

35. Allais, R.; Gobert, J. A multidisciplinary method for sustainability assessment of PSS: Challenges and developments. CIRP J. Manuf. Sci. Technol. 2016, 15, 56-64. [CrossRef]

36. Sousa-Zomer, T.T.; Cauchick Miguel, P.A. Sustainable business models as an innovation strategy in the water sector: An empirical investigation of a sustainable product-service system. J. Clean. Prod. 2018, 171, S119-S129. [CrossRef]

37. Shokohyar, S.; Mansour, S.; Karimi, B. A model for integrating services and product EOL management in sustainable product service system (S-PSS). J. Intell. Manuf. 2014, 25, 427-440. [CrossRef]

38. Chun, Y.Y.; Lee, K.M. Environmental impacts of the rental business model compared to the conventional business model: A Korean case of water purifier for home use. Int. J. Life Cycle Assess. 2017, 22, 1096-1108. [CrossRef]

39. Sousa-Zomer, T.T.; Magalhães, L.; Zancul, E.; Cauchick-Miguel, P.A. Exploring the challenges for circular business implementation in manufacturing companies: An empirical investigation of a pay-per-use service provider. Resour. Conserv. Recycl. 2018, 135, 3-13. [CrossRef]

40. Mourtzis, D.; Vlachou, A.; Zogopoulos, V. Cloud-Based Augmented Reality Remote Maintenance through Shop-Floor Monitoring: A Product-Service System Approach. J. Manuf. Sci. Eng. 2017, 139, 061011. [CrossRef]

41. Pagoropoulos, A.; Laumann Kjær, L.; Axel Bejbro Andersen, J.; McAloone, T.C. The influence of costs and benefits' analysis on service strategy formulation: Learnings from the shipping industry. Cogent Eng. 2017, 4. [CrossRef]

42. Fargnoli, M.; Costantino, F.; Di Gravio, G.; Tronci, M. Product service-systems implementation: A customized framework to enhance sustainability and customer satisfaction. J. Clean. Prod. 2018, 188, 387-401. [CrossRef]

43. Scheepens, A.E.; Vogtländer, J.G.; Brezet, J.C. Two life cycle assessment (LCA) based methods to analyse and design complex (regional) circular economy systems. Case: Making water tourism more sustainable. J. Clean. Prod. 2016, 114, 257-268. [CrossRef]

44. Firnkorn, J.; Müller, M. Selling Mobility instead of Cars: New Business Strategies of Automakers and the Impact on Private Vehicle Holding. Bus. Strateg. Environ. 2012, 21, 264-280. [CrossRef]

45. Firnkorn, J.; Müller, M. What will be the environmental effects of new free-floating car-sharing systems? The case of car2go in Ulm. Ecol. Econ. 2011, 70, 1519-1528. [CrossRef] 
46. Catulli, M.; Cook, M.; Potter, S. Product Service Systems Users and Harley Davidson Riders: The Importance of Consumer Identity in the Diffusion of Sustainable Consumption Solutions. J. Ind. Ecol. 2017, 21, 1370-1379. [CrossRef]

47. Amaya, J.; Lelah, A.; Zwolinski, P. Design for intensified use in product-service systems using life-cycle analysis. J. Eng. Des. 2014, 25, 280-302. [CrossRef]

48. Lee, S.; Geum, Y.; Lee, H.; Park, Y. Dynamic and multidimensional measurement of product-service system (PSS) sustainability: A triple bottom line (TBL)-based system dynamics approach. J. Clean. Prod. 2012, 32, 173-182. [CrossRef]

49. Zhang, W.; Guo, J.; Gu, F.; Gu, X. Coupling life cycle assessment and life cycle costing as an evaluation tool for developing product service system of high energy-consuming equipment. J. Clean. Prod. 2018, 183, 1043-1053. [CrossRef]

50. Pascual, R.; Siña, M.; Santelices, G.; Román, M.; López Droguett, E. Optimal channel coordination in use-based product-service system contracts. Int. J. Prod. Res. 2017, 55, 6946-6956. [CrossRef]

51. Kanda, W.; Sakao, T.; Hjelm, O. Components of business concepts for the diffusion of large scaled environmental technology systems. J. Clean. Prod. 2016, 128, 156-167. [CrossRef]

52. Tukker, A. Eight types of product-service system: Eight ways to sustainability? Experiences from suspronet. Bus. Strateg. Environ. 2004, 13, 246-260. [CrossRef]

53. Hsieh, H.-F.; Shannon, S.E. Three Approaches to Qualitative Content Analysis. Qual. Health Res. 2005, 15, 1277-1288. [CrossRef]

54. Lewandowski, M. Designing the Business Models for Circular Economy-Towards the Conceptual Framework. Sustainability 2016, 8, 43. [CrossRef]

55. Moreno, M.; de los Rios, C.; Rowe, Z.; Charnley, F. A Conceptual Framework for Circular Design. Sustainability 2016, 8, 937. [CrossRef]

56. Planing, D.P. Business Model Innovation in a Circular Economy-Reasons for Non-Acceptance of Circular Business Models. Open J. Bus. Model Innov. 2015, 1.

57. Ellen MacArthur Foundation. Towards a Circular Economy: Business Rationale for an Accelerated Transition; Ellen MacArthur Foundation: Cowes, UK, 2015; p. 19.

58. Lacy, P.; Rutqvist, J. Waste to Wealth, 1st ed.; Palgrave Macmillan: Basingstoke, UK, 2015; ISBN 9781137530684.

59. Hamers, L.; Hemeryck, Y.; Herweyers, G.; Janssen, M.; Keters, H.; Rousseau, R.; Vanhoutte, A. Similarity measures in scientometric research: The Jaccard index versus Salton's cosine formula. Inf. Process. Manag. 1989, 25, 315-318. [CrossRef]

60. Osterwalder, A.; Pigneur, Y. Business Model Generation, 1st ed.; John Wiley \& Sons, Inc.: Hoboken, NJ, USA, 2010; ISBN 9780470876411.

61. Ayres, R.U. Industrial metabolism: Theory and practice. In The Greening of Industrial Ecosystems; National Academy Press: Washington, DC, USA, 1994; pp. 23-37.

62. King, A.M.; Burgess, S.C.; Ijomah, W.; McMahon, C.A. Reducing waste: Repair, recondition, remanufacture or recycle? Sustain. Dev. 2006, 14, 257-267. [CrossRef]

63. Stahel, W.R. The Utilization-Focused Service Economy. Resource Efficiency and Product Life Extension. In The Greening of Industrial Ecosystems; National Academy Press: Washington, DC, USA, 1994; pp. 178-190, ISBN 0309049377.

64. Thierry, M.; Salomon, M.; Van Nunen, J.; Van Wassenhove, L. Strategic Issues in Product Recovery Management. Calif. Manage. Rev. 1995, 37, 114-136. [CrossRef]

65. Bocken, N.M.P.; Short, S.W.; Rana, P.; Evans, S. A literature and practice review to develop sustainable business model archetypes. J. Clean. Prod. 2014, 65, 42-56. [CrossRef]

66. Gutowski, T.G.; Sahni, S.; Boustani, A.; Graves, S.C. Remanufacturing and Energy Savings. Environ. Sci. Technol. 2011, 45, 4540-4547. [CrossRef]

67. Intlekofer, K.; Bras, B.; Ferguson, M. Energy implications of product leasing. Environ. Sci. Technol. 2010, 44, 4409-4415. [CrossRef]

(C) 2019 by the authors. Licensee MDPI, Basel, Switzerland. This article is an open access article distributed under the terms and conditions of the Creative Commons Attribution (CC BY) license (http://creativecommons.org/licenses/by/4.0/). 